\title{
Comparative toxicity and biodistribution assessments in rats following subchronic oral exposure to copper nanoparticles and microparticles
}

In-Chul Lee ${ }^{1,2}$, Je-Won Ko ${ }^{1}$, Sung-Hyeuk Park ${ }^{1}$, Na-Rae Shin ${ }^{1}$, In-Sik Shin ${ }^{1}$, Changjong Moon ${ }^{1}$, Je-Hein Kim³, Hyoung-Chin $\mathrm{Kim}^{4^{*}}$ and Jong-Choon Kim ${ }^{1 *}$

\begin{abstract}
Background: Copper nanoparticles (Cu NPs) have great potential in electronics and biomedical fields because of their efficient thermodynamic and anti-microbial properties. However, their potential toxic effects and kinetic data following repeated exposure are still unclear.

Methods: We evaluated the physicochemical properties of Cu NPs $(25 \mathrm{~nm})$ and copper microparticles (Cu MPs, 14-25 $\mu \mathrm{m}$ ). Comparative in vivo toxicity of Cu NPs and Cu MPs was evaluated by conducting a 28-day repeated oral dose study at equivalent dose levels of 0, 100, 200, and $400 \mathrm{mg} / \mathrm{kg} /$ day (vehicle, $1 \%$ hydroxypropyl methylcellulose). We determined Cu levels in the blood, tissues, urine, and feces by using inductively coupled plasma mass spectrometry.

Results: The solubility of Cu NPs and Cu MPs was 84.5 and 17.2\%, respectively, in an acidic milieu; however, they scarcely dissolved in vehicle or intestinal milieus. The specific surface area of Cu NPs and Cu MPs was determined to be 14.7 and $0.16 \mathrm{~m}^{2} / \mathrm{g}$, respectively. Cu NPs exhibited a dose-dependent increase of Cu content in the blood and tested organs, with particularly high levels of $\mathrm{Cu}$ in the liver, kidney, and spleen. Only for liver and kidney increased Cu levels were found in Cu MPs-treated rats. Cu NPs caused a dose-related increase in Cu levels in urine, whereas Cu MPs did not affect the urine Cu levels. Extremely high levels of $\mathrm{Cu}$ were detected in the feces of $\mathrm{Cu}$ MPs-treated rats, whereas much lower levels were detected in the feces of Cu NPs-treated rats. A comparative in vivo toxicity study showed that Cu NPs caused damages to red blood cells, thymus, spleen, liver, and kidney at $\geq 200 \mathrm{mg} / \mathrm{kg} /$ days, but Cu MPs did not cause any adverse effects even at the highest dose.

Conclusions: Overall, the in vivo repeated dose toxicity study of Cu NPs and Cu MPs demonstrated that large surface area and high solubility in physiological milieus could directly influence the toxicological responses and biodistribution of Cu particles when administered orally. Under these experimental conditions, the no-observedadverse-effect levels of Cu NPs and Cu MPs were determined to be 100 and $\geq 400 \mathrm{mg} / \mathrm{kg} /$ day, respectively.
\end{abstract}

Keywords: Copper nanoparticles, Copper microparticles, Comparative toxicity, Biodistribution

\footnotetext{
* Correspondence: hckim@kribb.re.kr; toxkim@jnu.ac.kr

${ }^{4}$ Laboratory Animal Resource Center, Korea Research Institute of Bioscience

and Biotechnology, ChungBuk 28116, Republic of Korea

${ }^{1}$ College of Veterinary Medicine BK21 Plus Project Team, Chonnam National

University, Gwangju 61186, Republic of Korea

Full list of author information is available at the end of the article
} 


\section{Background}

Nanomaterials are defined as materials that have at least one dimension in the 1 to $100 \mathrm{~nm}$ range, which were generated by accidentally or engineering. The engineered nanoparticles (NPs) can be utilized in an applicationspecific manner by modifying their size, surface properties, and shape. Thus, in recent years, remarkable progress has been made in the area of nanotechnology as evident from its widespread use in textile, electronics, cosmetics, and foods [1]. The physicochemical properties of NPs may determinate toxicological behavior in vivo by making them interact with biological systems and be absorbed more than bulk chemicals via various routes [2, 3]. Hence, NPs tend to exhibit quite different toxicological profiles in vivo compared to the larger particles [4-7]. Physiological conditions also influence the interaction between biological systems and NPs and they can determine the fate and biosafety of NPs [8]. Recently, increased usage of NPs raises concerns on their health risks and environmental effects [9-11].

Copper $(\mathrm{Cu})$ is an essential element required for normal physiological functioning, including drug/xenobiotic metabolism, carbohydrate metabolism, and the antioxidant defense system $[12,13]$. The general population is exposed to $\mathrm{Cu}$ through inhalation, consumption of food and water, and dermal contact with air, water, and soil that contains $\mathrm{Cu}$. The toxicity of $\mathrm{Cu}$ and its compounds has been studied for decades. A report of the available data has been given in the "Toxicological Profile for Copper" from the Agency for Toxic Substances and Disease Registry of the U.S. Public Health Service [14]. When intake of $\mathrm{Cu}$ exceeds the range of biological tolerance, it can cause adverse effects, including damage to liver, kidney, immune system, and gastrointestinal distress [14]. Although the toxic effects of $\mathrm{Cu}$ and its compounds have been studied, several studies reported gaps concerning the risk caused by $\mathrm{Cu}$ in the form of NPs $[7,15]$.

Among the various types of nanomaterials, metalbased NPs are used in the manufacture of hundreds of commercial products, and their industrial and consumer applications are expected to increase the chances of their exposure to the public $[10,11]$. In particular, $\mathrm{Cu}$-based NPs are widely used in a variety of established and emerging technologies, including catalysts, solar energy conversion, and antimicrobial agents, because of their distinct thermophysical properties and antimicrobial activities [16-20]. Despites widespread applications and the growing presence of $\mathrm{Cu}$-containing nanoproducts, there is only limited information on the potential risks of exposure to $\mathrm{Cu}$-based NPs compared to other NPs $[17,21]$. To date, many reports regarding the in vitro toxicity of $\mathrm{Cu}$-based NPs are available. $\mathrm{Cu}$-based NPs induce cytotoxic effects associated with increase of reactive oxygen species in various cell lines, including human laryngeal epithelial cells and human alveolar type-I epithelial cells [22-25]. Cu NPs showed a higher toxicity than their oxide nanoparticles ( $\mathrm{CuO} \mathrm{NPs}$ ) in HL60 cells [26]. CuO NPs are highly toxic compared to carbon nanotubes and other metal oxide NPs [27]. However, only a few studies have explored in vivo toxicity; these studies revealed biochemical and histological alterations related to liver, kidney, and spleen after a single or short-term exposure of $\mathrm{Cu}$ NPs [7, 15, 28, 29]. To our knowledge, there has been no report regarding the potential effects and biodistribution of $\mathrm{Cu}$ NPs following long-term exposure. Therefore, for further practical applications, it is necessary to evaluate the in vivo toxicity of $\mathrm{Cu}$ NPs and their biodistribution after subchronic exposure for the purpose of risk assessment.

Herein, we investigated the in vivo toxicity of $\mathrm{Cu}$ NPs and $\mathrm{Cu}$ microparticles ( $\mathrm{Cu}$ MPs) following 28-day repeated oral dose in rats by evaluating biochemical, hematological, and histopathological parameters. The oral route was used because gastrointestinal exposure to nanomaterials has the potential for wide public exposure to higher doses and more frequent ingestion [30, 31]. Further, we investigated absorption, tissue distribution, and excretion to elucidate the main accumulation sites and elimination routes. In this work, we report for the first time, to the best of our knowledge, the in vivo toxicity and biodistribution of $\mathrm{Cu}$ NPs by conducting a repeated dose toxicity study.

\section{Results and discussion}

\section{Physiochemical characterization of Cu NPs and Cu MPs}

The physiochemical characteristics of $\mathrm{Cu}$ NPs and $\mathrm{Cu}$ MPs are summarized in Table 1. The morphology and actual size of $\mathrm{Cu}$ NPs and $\mathrm{Cu}$ MPs were characterized by transmission electron microscopy (TEM) and scanning electron microscopy (SEM). The morphology of NPs or MPs was spherical, and the actual size of individual particles was found to be $32.7 \pm 10.45 \mathrm{~nm}$ (300 counts) and $25.3 \pm 6.64 \mu \mathrm{m}$ (100 counts), respectively (Fig. 1a-d). The purities of $\mathrm{Cu}$ NPs and $\mathrm{Cu}$ MPs were determined as 98.15 and $99.06 \%$, respectively, using energy dispersive $\mathrm{X}$-ray spectroscopy (EDX) analysis on the same images (data not shown). The specific surface area of $\mathrm{Cu}$ NPs and $\mathrm{Cu}$ MPs was measured as 14.7 and $0.16 \mathrm{~m}^{2} / \mathrm{g}$, respectively using the Brunauer-Emmett-Teller (BET) method. Suspension stability and surface charge reflect the interaction of NPs with physiological milieus because of their large surface area/volume ratio $[32,33]$. The zeta potential of the $\mathrm{Cu}$ NPs was $25.5 \pm 0.8 \mathrm{mV}$ for $\mathrm{pH} 1.5$, $1.32 \pm 1.2 \mathrm{mV}$ for $\mathrm{pH} 6.8$, and $-6.2 \pm 0.2 \mathrm{mV}$ for $\mathrm{pH} 7.8$. Dynamic light scattering (DLS) measurements revealed that $\mathrm{Cu}$ NPs agglomerate in intestinal ( $\mathrm{pH} 7.8$ ) and vehicle $(\mathrm{pH}$ 6.8) milieus with the hydrodynamic 
Table 1 Physiochemical characterization

\begin{tabular}{llll}
\hline Items & & Cu NPs & Cu MPs \\
\hline Shape & & Spherical & Spherical \\
Primary size $^{\mathrm{a}}$ & & $32.7 \pm 10.5 \mathrm{~nm}$ & $25.3 \pm 6.6 \mu \mathrm{m}$ \\
${\text { Hydrodynamic size }(\mathrm{nm})^{\mathrm{b}}}$ & $\mathrm{pH} \mathrm{1.5}$ & n.a & n.a \\
& $\mathrm{pH} \mathrm{6.5}$ & $516 \pm 116.9$ & n.a \\
& $\mathrm{pH} \mathrm{7.8}$ & $334 \pm 128.3$ & n.a \\
Surface area $\left(\mathrm{m}^{2} / \mathrm{g}\right)^{\mathrm{c}}$ & & 14.7 & 0.16 \\
Zeta potential $(\mathrm{mV})^{d}$ & $\mathrm{pH} \mathrm{1.5}$ & $25.5 \pm 0.8$ & n.a \\
& $\mathrm{pH} \mathrm{6.5}$ & $1.32 \pm 1.2$ & n.a \\
& $\mathrm{pH} \mathrm{7.8}$ & $-6.2 \pm 0.2$ & n.a \\
\hline
\end{tabular}

Note

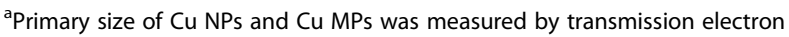
microscopy (300 counts and 100 counts, respectively)

${ }^{\mathrm{b}} \mathrm{Hydrodynamic}$ size of Cu NPs was measured by a dynamic light scattering method

'Surface area was measured by the Brunauer-Emmett-Teller method $\left(\mathrm{N}_{2}\right.$ gas)

${ }^{\mathrm{d}}$ Zeta potential was measured using electrophoretic light scattering method

under $\mathrm{pH} 1.5, \mathrm{pH} 6.5$ and $\mathrm{pH} 7.8$ conditions

n.a. not available

diameters of $334.8 \pm 128.26$ and $516.4 \pm 116.9 \mathrm{~nm}$, respectively. However, in an acidic milieu ( $\mathrm{pH} 1.5)$, the hydrodynamic diameter of $\mathrm{Cu}$ NPs was not determined because $\mathrm{Cu}$ NPs rapidly dissolved in acidic conditions and particle numbers were not enough to determine hydrodynamic diameter. These findings suggest the tendency of $\mathrm{Cu}$ NPs to aggregate/agglomerate in suspension or the intestinal milieu. However, the NP form presents a greater specific surface area compared with the same compositional particles of micro size scale that may cause different biological responses and modulate their fate in biological systems.

\section{Dissolution of Cu NPs and Cu MPs in physiological conditions}

The dissolution of NPs in gastrointestinal fluids may help predict uptake and blood concentrations. The release of toxic ions has the potential to influence the toxicity of NPs [34-36]. Most NPs are rarely soluble at normal physiological conditions; however, their dissolution can be accelerated in acidic conditions [37, 38]. We evaluated the solubility of $\mathrm{Cu}$ NPs and $\mathrm{Cu}$ MPs (5 mg/mL each) under simulated gastric $\mathrm{pH}(\mathrm{pH} 1.5)$, vehicle $\mathrm{pH}(\mathrm{pH}$ 6.8), and intestinal $\mathrm{pH}(\mathrm{pH} 7.8)$ after a $24 \mathrm{~h}$ incubation. $\mathrm{Cu}$ NPs in an acidic milieu showed bluish color changes within $10 \mathrm{~min}$ (Fig. 1e). After monitoring for up to $24 \mathrm{~h}, \mathrm{Cu}$ NPs showed $84.5 \%$ solubility in an acidic milieu, whereas only minimal dissolution was observed in vehicle $(0.65 \%)$ and intestinal (0.09\%) conditions (Fig. 1f). In contrast, $\mathrm{Cu}$ MPs showed much lower solubility compared to $\mathrm{Cu} \mathrm{NPs}$, even in an acidic milieu (pH 1.5, 17.2; pH 6.8, 0.04; and pH 7.8, $0.03 \%$ ). It has been reported that $\mathrm{Cu}$ NPs have high solubility in an acidic milieu with high positive charge at zeta potential analysis [15, 39]. Compared with Cu MPs, the large specific surface area of $\mathrm{Cu}$ NPs can lead to high reactivity and drastic interaction with hydrogen ions $\left(\mathrm{H}^{+}\right)$in a gastric milieu [15]. Because the $\mathrm{pH}$ of gastric fluid is between 1.5 and 2.0, $\mathrm{Cu}$ NPs may be dissolved in the stomach, and dissociated $\mathrm{Cu}$ ions can be absorbed into the systemic circulation when administered orally. The dissociation of $\mathrm{Cu}$ NPs after gastric emptying is prohibited in the basic milieu of the small intestine. Thus, the residence time in the stomach may influence the dissolution of $\mathrm{Cu}$ NPs. $\mathrm{Cu}$ NPs quickly dissolved in gastric milieus, and the undissolved NPs showed a delayed retention in the stomach after $24 \mathrm{~h}$ in mice exposed to $\mathrm{Cu}$ NPs, which may lead to durative interaction and persistent $\mathrm{Cu}$ ion generation in vivo [15].

\section{Absorption, distribution, and excretion of $\mathrm{Cu}$}

The dissolution of NPs in physiological conditions and the physicochemical features of NPs are both likely to influence the absorption and biological response of NPs when administered orally $[3,35,40]$. The $\mathrm{Cu}$ levels in blood reflect the absorption of $\mathrm{Cu}$ following oral exposure of $\mathrm{Cu}$ NPs or $\mathrm{Cu}$ MPs. $\mathrm{Cu}$ levels in the blood of $\mathrm{Cu}$ NPs-treated rats showed a dose-dependent increase and were 4-fold higher than that of the vehicle control group $(3.33 \pm 0.89 \mu \mathrm{g} / \mathrm{g}$ vs. $0.83 \pm 0.21 \mu \mathrm{g} / \mathrm{g})$. In contrast, oral exposure to $\mathrm{Cu}$ MPs did not lead to an increase in blood $\mathrm{Cu}$ levels, which were not different from the vehicle control group $(1.16 \pm 0.30 \mu \mathrm{g} / \mathrm{g}$ vs. $0.83 \pm 0.21 \mu \mathrm{g} / \mathrm{g})$ (Fig. 2a). Exposure to nano- $\mathrm{Cu}(75 \mathrm{mg} / \mathrm{kg})$ markedly elevates serum $\mathrm{Cu}$ level (3.5-fold higher) compared to a minimal increase in $\mathrm{Cu}$ from the same mass of micro- $\mathrm{Cu}$ exposed mice at $72 \mathrm{~h}$ after single oral dose [15]. Consistent with the results of a previous report, $\mathrm{Cu}$ NPs-treated rats showed 2.9-fold higher levels of $\mathrm{Cu}$ than that in rats exposed to a corresponding high dose of $\mathrm{Cu}$ MPs at $24 \mathrm{~h}$ after the last administration. With a delayed retention in the stomach, the higher levels of $\mathrm{Cu}$ in the blood of rats treated with $\mathrm{Cu}$ NPs compared to $\mathrm{Cu}$ MPs indicate that more $\mathrm{Cu}$ ions were dissociated from $\mathrm{Cu}$ NPs and absorbed into systemic circulation. Moreover, high and rapid dissolution of $\mathrm{Cu}$ NPs in the gastric milieu suggests that $\mathrm{Cu}$ NPs may be mainly absorbed as ionic forms rather than nanoparticulate states. Absorbed $\mathrm{Cu}$ ions could enter into systemic circulation and be distributed in various tissues. Generally, exposure of human body to $\mathrm{Cu}$ NPs can occur through different routes (e.g., inhalation, ingestion, injection or physical contact). Absorbed NPs may interact with biomolecules such as proteins, nucleic acids, lipids, and even biological metabolites [41]. Of particular importance is the absorption of proteins on the surface of NPs and form the NP-protein complexes, which referred to as the NP-protein corona. The protein corona alters the size and interfacial 


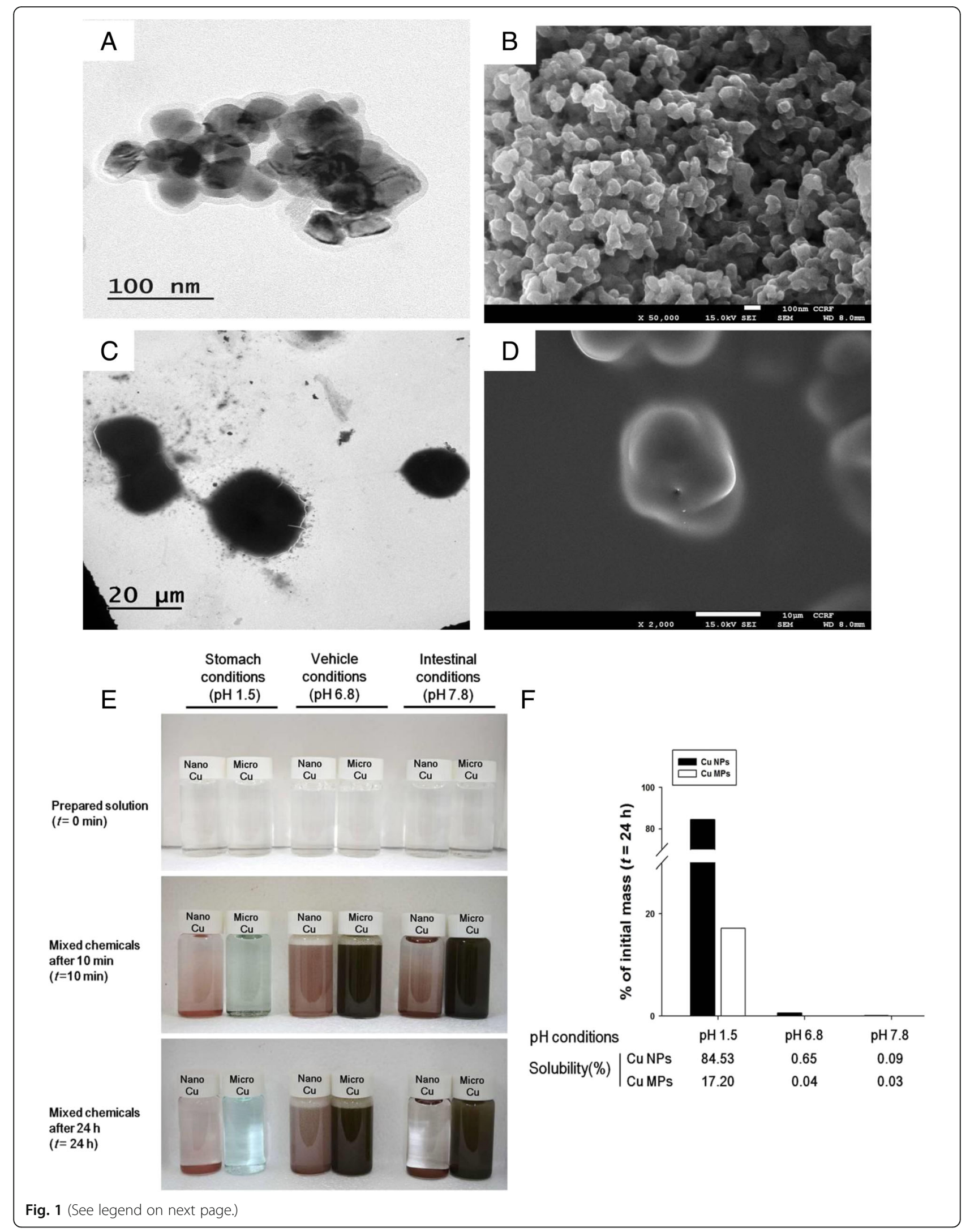


(See figure on previous page.)

Fig. 1 Morphology and dissolution of copper nanoparticles (Cu NPs) and copper microparticles (Cu MPs). Transmission electron microscopy (TEM) and scanning electron microscopy (SEM) images of (a, b) Cu NPs and (c, d) Cu MPs show generally spherical shape. e The color changes of artificial gastric fluid (AGF; pH 1.5), vehicle (1 \% hydroxypropyl methylcellulose, HPMC; pH 6.5), and deionized water (pH 7.8) solution before (top, $t=0$ ) or after mixing with the Cu NPs and Cu MPs for $10 \mathrm{~min}$ (middle, $t=10 \mathrm{~min}$ ) and $24 \mathrm{~h}$ (bottom, $t=24 \mathrm{~h}$ ). f Dissolution ratios of Cu NPs and $\mathrm{Cu}$ MPs in AGF, vehicle ( $\mathrm{pH}$ 6.5), and deionized water ( $\mathrm{pH}$ 7.8) milieus, which simulated in vivo physiological conditions. Cu NPs and Cu MPs $(5 \mathrm{mg} / \mathrm{mL}$ ) were suspended in above solutions and percentage of dissolution was measured using inductively coupled plasma mass spectrometry after $24 \mathrm{~h}$ of incubation ( $\mathrm{t}=24 \mathrm{~h}$ )

composition of NPs, giving it a new biological identity, which was determine the agglomeration, uptake, translocation, accumulation, as well as toxicological response [42]. Thus, further study to explanation for interaction between $\mathrm{Cu}$ NPs and proteins is needed.

In vivo biodistribution of $\mathrm{Cu}$ NPs can provide essential information regarding their accumulation sites. $\mathrm{Cu}$ levels in the tested organs of $\mathrm{Cu}$ NPs-exposed groups showed a dose-dependent increase when compared with that in the vehicle control group (Fig. $2 \mathrm{~b}-\mathrm{g}$ ). The main organs with accumulation of $\mathrm{Cu}$ were liver (109-fold higher, $2038.1 \pm 758.36 \mu \mathrm{g} / \mathrm{g}$ vs. $18.7 \pm 5.79 \mu \mathrm{g} / \mathrm{g}$ ), kidney (34fold higher, $950.0 \pm 197.58 \mu \mathrm{g} / \mathrm{g}$ vs. $27.7 \pm 8.62 \mu \mathrm{g} / \mathrm{g}$ ), and spleen (38-fold higher, $171.7 \pm 23.64 \mu \mathrm{g} / \mathrm{g}$ vs. $4.5 \pm$ $1.59 \mu \mathrm{g} / \mathrm{g})$. Cu levels in nano- $\mathrm{Cu}$ treated mice showed a significant increase in the kidney, whereas micro-Cu did not elevate $\mathrm{Cu}$ levels in the kidney after a single oral dose $(70 \mathrm{mg} / \mathrm{kg})$ [15]. Feng et al. [43] reported that liver,

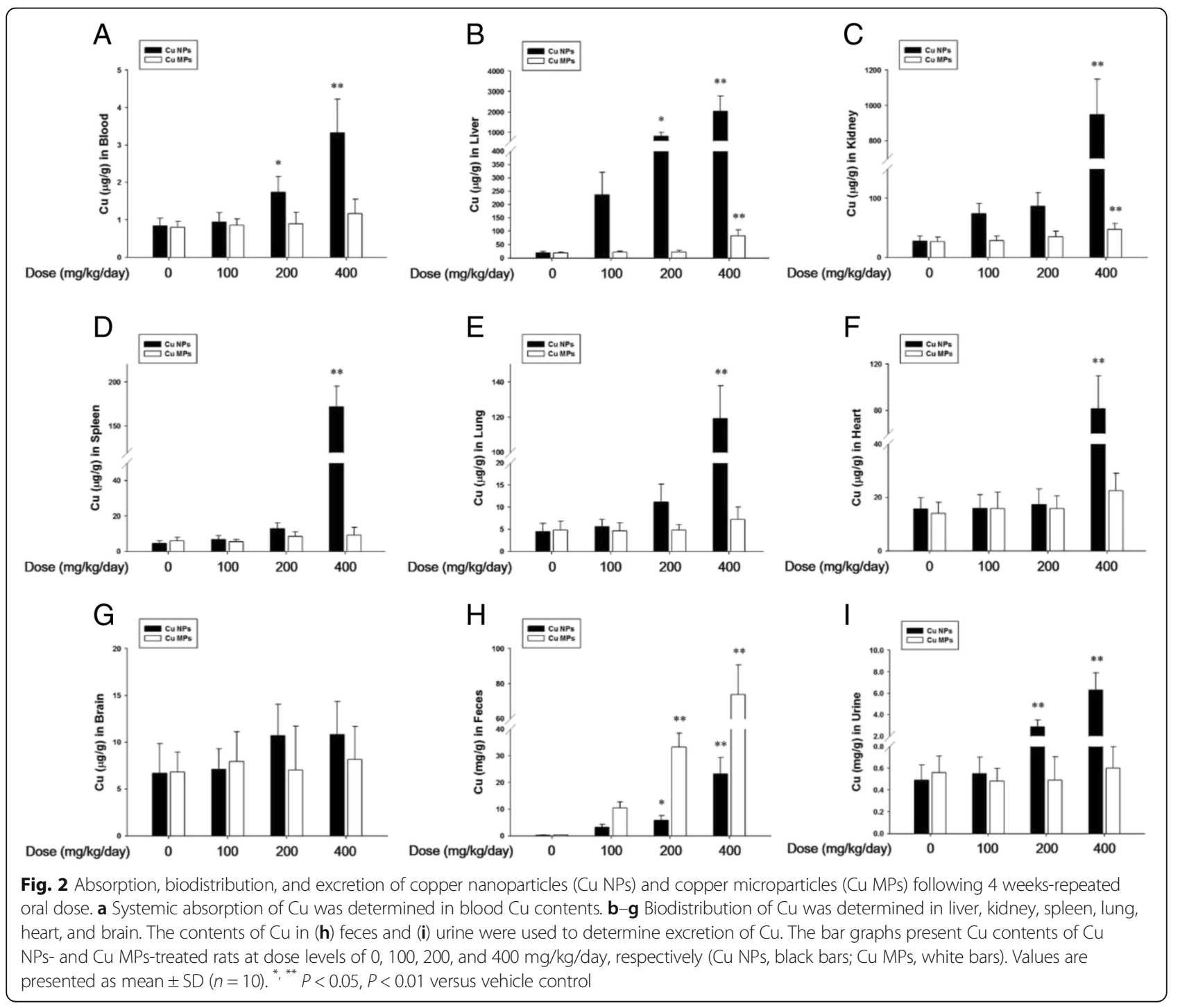


spleen, lung, and kidney appear to be the major organs for accumulation of $\mathrm{Cu}$ sulfide nanoplates after intravenous injection. Thus, the biodistribution of $\mathrm{Cu}$ indicated that $\mathrm{Cu}$ from $\mathrm{Cu}$ NPs was mainly distributed in the liver, kidney, and spleen. Further, accumulated $\mathrm{Cu}$ in these organs can be a toxic reservoir based on their toxic potential. However, equivalent dose levels of $\mathrm{Cu}$ MPs are not only lower than those of $\mathrm{Cu}$ NPs, but also showed no doseresponse increase in the tested organs, except in the liver $(83.1 \pm 20.94 \mu \mathrm{g} / \mathrm{g})$ and kidney $(46.7 \pm 10.14 \mu \mathrm{g} / \mathrm{g})$. This low distribution was due to the minimal absorption rate of $\mathrm{Cu}$ MPs.

The excretion of $\mathrm{Cu}$ was consistent with the absorption and distribution patterns of $\mathrm{Cu}$ NPs or Cu MPs. The levels of $\mathrm{Cu}$ in urine from the $\mathrm{Cu}$ NPs-treated group showed a significant increase with clear dose-response when compared to that in the vehicle control group (12.8-fold higher, $6.31 \pm 1.59 \mu \mathrm{g} / \mathrm{g}$ vs. $0.49 \pm 0.21 \mu \mathrm{g} / \mathrm{g}$ ) (Fig. 2h). In contrast, only trace $\mathrm{Cu}$ levels were observed in the urine of the $\mathrm{Cu}$ MPs-treated groups $(0.60 \pm 0.19 \mu \mathrm{g} / \mathrm{g}$ vs. $0.49 \pm$ $0.21 \mu \mathrm{g} / \mathrm{g}) . \mathrm{Cu}$ levels in the feces of $\mathrm{Cu}$ NPs treated rats showed clear dose-response when compared to that in the vehicle control group (115-fold higher, $26.2 \pm 8.41 \mathrm{mg} / \mathrm{g}$ vs. $0.2 \pm 0.09 \mathrm{mg} / \mathrm{g})$. $\mathrm{Cu}$ MPs treated rats showed extremely high levels of $\mathrm{Cu}$ in the feces, which were 2.8 -fold higher than that in $\mathrm{Cu}$ NPs treated-rats $(73.7 \pm 16.98 \mathrm{mg} / \mathrm{g}$ vs. $26.2 \pm 8.41 \mathrm{mg} / \mathrm{g}$ ) (Fig. 2i). Ingested $\mathrm{Cu}$ ions are mainly metabolized in the liver, and the major excretory route is via liver/bile [44]. The dissociation of $\mathrm{Cu}$ NPs after gastric emptying is prohibited in the basic milieu of the small intestine, and then unabsorbed NPs are excreted as feces [15]. Thus, extremely high levels of $\mathrm{Cu}$ in feces suggest that most of the absorbed $\mathrm{Cu}$, dissociated from $\mathrm{Cu}$ NPs, or unabsorbed $\mathrm{Cu}$ NPs were predominantly excreted through feces; small amounts were excreted via the kidney/urine route. Most of the unabsorbed $\mathrm{Cu}$ MPs were also eliminated from gastro-intestinal tracts via the feces.

\section{Clinical signs, body weights, and food consumption}

Manifestations of toxicity, including anorexia, diarrhea, lethargy, and body weight loss, were observed in rats treated with $\mathrm{Cu}$ NPs [28]; these manifestations were similar to the effects of excessive $\mathrm{Cu}$ compound treatment [45-47]. In this study, treatment-related clinical signs observed in the high dose group of $\mathrm{Cu}$ NPs were consistent with toxic manifestations observed in a previous study. The body weight and the amount of food consumption in the high dose group of $\mathrm{Cu}$ NPs decreased significantly during the test period (Fig. 3a and b). In contrast, only test article-colored feces were observed in the high dose group of $\mathrm{Cu}$ MPs. The body weight and food consumption of the $\mathrm{Cu}$ MPs-treated groups showed no significant changes, even at the high dose, compared to that in the vehicle control group (Fig. 3c and d).

\section{Urinalysis, serum biochemistry, and hematology}

It has been reported that oral exposure to $\mathrm{Cu}$ NPs cause imbalance of acid and base by interacting with $\mathrm{H}^{+}$, resulting in metabolic alkalosis [15]. In a chronic metabolic alkalosis state, bicarbonate excretion ceased and led to a state of paradoxical aciduria [48]. The decreased urine $\mathrm{pH}$ observed in the high dose group of $\mathrm{Cu}$ NPs may be due to chronic metabolic alkalosis caused by sub-chronic exposure to $\mathrm{Cu}$ NPs (Additional file 1: Table $\mathrm{S} 1)$. Other urinalysis parameters, including urine protein (PRO), occult blood (OB), leukocytes (LEU), specific gravity (SG), ketone body (KET), and nitrite (NIT), were increased significantly in the high dose group of $\mathrm{Cu}$ NPs. Hematological findings revealed that repeated exposure to $\mathrm{Cu}$ NPs resulted in red blood cell (RBC) destruction, which was characterized by a reduction of $\mathrm{RBC}$, hemoglobin (HB), hematocrit (HCT), mean corpuscular volume $(\mathrm{MCV})$, mean corpuscular hemoglobin $(\mathrm{MCH})$, and mean corpuscular hemoglobin concentration $(\mathrm{MCHC})$, as well as an increase in reticulocytes (RET) (Table 2). This interpretation was well supported by increased yellow pigmentation in the spleen. Chronic $\mathrm{Cu}$ intoxication causes hemolytic anemia with diverse hematological changes, including decreased $R B C, H B$, HCT, MCV, MCH and white blood cells (WBC) in rodents $[46,49,50]$, which were consistent with the results of this study. In addition, the changes in the hematology indicate a microcytic anemia that generally observed with iron deficiency. Elevated levels of $\mathrm{Cu}$ levels have been shown to competitively inhibit iron absorption and utilization and to be correlated with diminution in serum iron levels $[51,52]$. In the differential WBC count, a dose-dependent decrease in the percentage of lymphocytes (LYM) implied that $\mathrm{Cu}$ NPs might have adverse effects on the immune system, which was well correlated with the reduction of cellularity seen in the thymus and spleen (Fig. 4). The increased percentages of neutrophils (NEU) and monocytes $(\mathrm{MON})$ were thought to be related to the inflammatory response of the affected organs and the decreased LYM percentage (Table 2). These results indicated that $\mathrm{Cu}$ NPs might affect red blood cells and immune organs (spleen and thymus). As reported previously, $\mathrm{Cu}$ NPs caused liver and kidney damages with biochemical alterations, including increased aspartate aminotransferase (AST), alanine aminotransferase (ALT), total bilirubin (TBIL), blood urea nitrogen (BUN), and creatinine (CRE) $[28,29]$. With obvious changes in urinalysis parameters, $\mathrm{Cu}$ NPs treated rats showed a dose-related response in the increment of serum BUN, CRE, AST, ALT, TBIL, alkaline phosphatase (ALP), and lactate dehydrogenase (LDH), as well as the decrease of triglyceride (TG) and total protein (TP) with electrolytes disturbance (Table 3). These findings on the consequence 

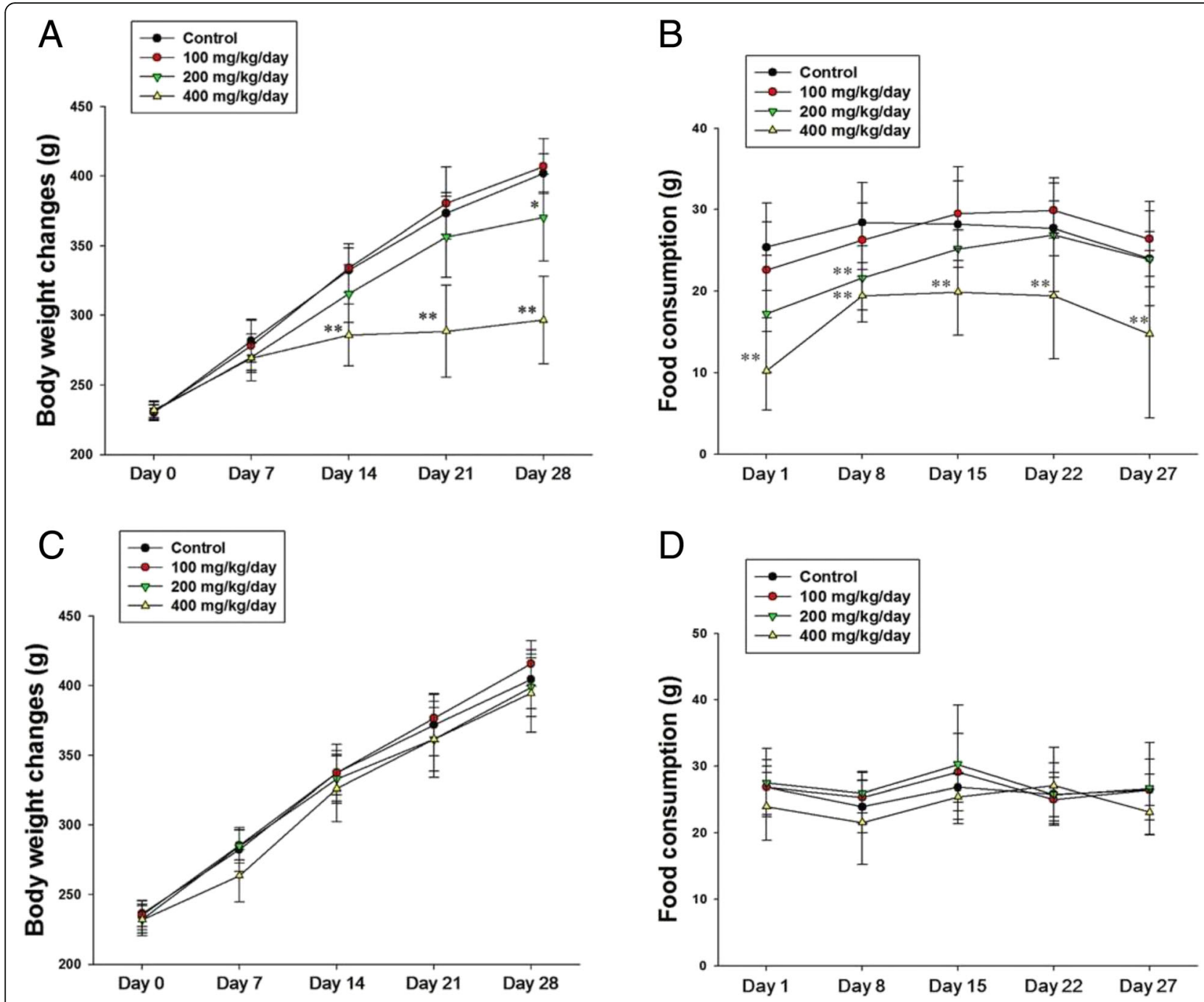

Fig. 3 Body weight changes and food consumption of copper nanoparticles (Cu NPs)- and copper microparticles (Cu MPs)-treated rats following 4 weeks-repeated oral dose. Repeated oral dose toxicity of Cu NPs and Cu MPs was assessed by determining (a, $\mathbf{c})$ Body weight changes and (b, d) food consumption of Cu NPs- and Cu MPs-treated rats. Values are presented as mean $\pm \mathrm{SD}(n=10)$. ${ }^{* * *} P<0.05, P<0.01$ versus vehicle control

of $\mathrm{Cu}$ NPs exposure proved that $\mathrm{Cu}$ NPs cause substantial damage to the liver and kidney. Collectively, $\mathrm{Cu}$ dissociated from $\mathrm{Cu}$ NPs mainly distributed into liver, kidney, and spleen, which caused obvious functional and structural damage. However, the parameters of urinalysis, serum biochemistry, and hematology were not affected by repeated exposure to $\mathrm{Cu}$ MPs (Additional file 1: Table S1, Tables 2 and 3).

\section{Histopathology and organ weight changes}

Our findings confirmed previous studies showing that a single or short-term oral exposure of $\mathrm{Cu}$ NPs induces severe damage to the kidney and liver $[7,15,28,29]$. The major histopathological findings, including mononuclear cell infiltration, dilated sinusoid, degenerated or binucleated hepatocytes in the liver, dilated tubules, cell debris or pink or purple-colored casts in tubules, degenerated tubular cells, and inflammatory cell infiltration in the kidney, were observed in the rats treated with $\mathrm{Cu}$ NPs (Table 4 and Fig. 5). Excessive $\mathrm{Cu}$ intake results in impairment of both cellular and humoral immune responses [53]. Recently, $\mathrm{Cu}$ (II) chloride causes apoptosis of splenocytes and thymocytes, especially $\mathrm{CD}^{+} \mathrm{T}$ cell death $[54,55]$. Exposure to nano- $\mathrm{Cu}$ caused dwindling of splenic units and reduction of lymphocytes [7]. In rats treated with the high dose of $\mathrm{Cu}$ NPs, the spleen exhibited atrophic white pulp, decreased number of follicles and cellularity, and yellow pigmentation, and the thymus displayed disrupted demarcation of medulla/cortex, decreased cellularity, and cytoplasmic vacuolation, 
Table 2 Hematological changes in male rats treated with Cu NPs and Cu MPs following 28 days-repeated oral dose

\begin{tabular}{|c|c|c|c|c|}
\hline \multirow[t]{2}{*}{ Items } & \multicolumn{4}{|c|}{ Cu NPs (mg/kg/day) } \\
\hline & 0 & 100 & 200 & 400 \\
\hline No. of rats & 10 & 10 & 10 & 10 \\
\hline $\operatorname{RBC}\left(10^{12} / \mathrm{L}\right)$ & $7.02 \pm 0.234^{a}$ & $6.69 \pm 0.388$ & $6.17 \pm 0.346^{* *}$ & $6.12 \pm 0.612^{* *}$ \\
\hline $\mathrm{HB}(\mathrm{g} / \mathrm{dL})$ & $16.78 \pm 1.212$ & $15.77 \pm 1.668$ & $12.70 \pm 1.628^{* *}$ & $11.80 \pm 1.187^{* *}$ \\
\hline HCT (\%) & $43.43 \pm 3.435$ & $42.50 \pm 2.432$ & $37.32 \pm 3.179^{* *}$ & $36.47 \pm 5.747^{* *}$ \\
\hline MCV (fl) & $53.73 \pm 4.388$ & $50.09 \pm 4.618$ & $43.63 \pm 9.582^{* *}$ & $43.60 \pm 4.486^{* *}$ \\
\hline $\mathrm{MCH}(\mathrm{pg})$ & $23.47 \pm 1.598$ & $21.31 \pm 2.788$ & $19.10 \pm 3.306^{* *}$ & $18.92 \pm 2.099^{* *}$ \\
\hline $\mathrm{MCHC}(\mathrm{g} / \mathrm{dL})$ & $34.68 \pm 2.770$ & $34.57 \pm 3.317$ & $33.05 \pm 4.339$ & $28.31 \pm 2.198^{* *}$ \\
\hline $\operatorname{PLT}\left(10^{9} / \mathrm{L}\right)$ & $1106.2 \pm 104.92$ & $1212.7 \pm 125.88$ & $1258.8 \pm 166.73^{*}$ & $1262.4 \pm 121.65^{*}$ \\
\hline RET (\%) & $2.3 \pm 0.23$ & $2.4 \pm 0.51$ & $2.7 \pm 0.48$ & $6.1 \pm 2.17^{* *}$ \\
\hline WBC $\left(10^{9} / L\right)$ & $11.2 \pm 0.95$ & $11.3 \pm 2.13$ & $8.5 \pm 3.03^{*}$ & $8.3 \pm 1.21^{* *}$ \\
\hline NEU (\%) & $11.9 \pm 0.95$ & $11.2 \pm 3.45$ & $23.9 \pm 5.41^{* *}$ & $36.6 \pm 8.15^{* *}$ \\
\hline LYM (\%) & $82.3 \pm 10.73$ & $82.3 \pm 12.79$ & $71.7 \pm 13.28$ & $52.7 \pm 20.17^{* *}$ \\
\hline MON (\%) & $2.2 \pm 0.39$ & $2.2 \pm 0.33$ & $2.3 \pm 0.51$ & $3.0 \pm 0.59^{* *}$ \\
\hline EOS (\%) & $1.7 \pm 0.39$ & $1.7 \pm 0.33$ & $1.6 \pm 0.53$ & $2.0 \pm 0.59$ \\
\hline BAS (\%) & $0.7 \pm 0.21$ & $0.8 \pm 0.18$ & $0.7 \pm 0.27$ & $0.7 \pm 0.19$ \\
\hline LUC (\%) & $0.7 \pm 0.13$ & $0.7 \pm 0.24$ & $1.0 \pm 0.19^{*}$ & $1.2 \pm 0.25^{* *}$ \\
\hline \multirow[t]{2}{*}{ Items } & \multicolumn{4}{|c|}{ Cu MPs (mg/kg/day) } \\
\hline & 0 & 100 & 200 & 400 \\
\hline No. of rats & 10 & 10 & 10 & 10 \\
\hline $\operatorname{RBC}\left(10^{12} / L\right)$ & $7.04 \pm 0.312$ & $7.20 \pm 0.286$ & $7.00 \pm 0.403$ & $6.96 \pm 0.388$ \\
\hline $\mathrm{HB}(\mathrm{g} / \mathrm{dL})$ & $16.65 \pm 1.326$ & $16.72 \pm 1.169$ & $15.96 \pm 1.563$ & $16.12 \pm 1.971$ \\
\hline HCT (\%) & $43.79 \pm 4.793$ & $43.61 \pm 4.201$ & $40.16 \pm 5.776$ & $41.63 \pm 3.304$ \\
\hline MCV (fl) & $53.81 \pm 5.716$ & $52.70 \pm 6.621$ & $52.63 \pm 4.184$ & $52.34 \pm 7.206$ \\
\hline $\mathrm{MCH}(\mathrm{pg})$ & $23.61 \pm 3.392$ & $24.32 \pm 2.562$ & $24.52 \pm 1.397$ & $22.93 \pm 4.257$ \\
\hline $\mathrm{MCHC}(\mathrm{g} / \mathrm{dL})$ & $34.71 \pm 3.392$ & $29.67 \pm 5.561$ & $32.09 \pm 3.397$ & $32.25 \pm 4.257$ \\
\hline $\operatorname{PLT}\left(10^{9} / \mathrm{L}\right)$ & $1179.7 \pm 202.53$ & $1047.4 \pm 218.36$ & $1259.8 \pm 187.54$ & $1236.5 \pm 232.71$ \\
\hline RET (\%) & $2.5 \pm 0.58$ & $2.6 \pm 0.37$ & $2.4 \pm 0.39$ & $2.7 \pm 0.44$ \\
\hline WBC $\left(10^{9} / \mathrm{L}\right)$ & $11.3 \pm 1.49$ & $11.9 \pm 2.48$ & $12.3 \pm 3.49$ & $11.56 \pm 2.23$ \\
\hline NEU (\%) & $12.2 \pm 2.23$ & $10.8 \pm 3.91$ & $13.2 \pm 4.45$ & $11.9 \pm 3.71$ \\
\hline LYM (\%) & $82.9 \pm 13.2$ & $85.0 \pm 22.47$ & $82.7 \pm 16.66$ & $83.5 \pm 13.09$ \\
\hline MON (\%) & $2.2 \pm 0.48$ & $2.3 \pm 0.31$ & $2.5 \pm 0.43$ & $2.3 \pm 0.54$ \\
\hline EOS (\%) & $1.6 \pm 0.42$ & $1.5 \pm 0.24$ & $1.6 \pm 0.40$ & $1.8 \pm 0.48$ \\
\hline BAS (\%) & $0.7 \pm 0.23$ & $0.7 \pm 0.17$ & $0.8 \pm 0.13$ & $0.7 \pm 0.21$ \\
\hline LUC (\%) & $0.7 \pm 0.22$ & $0.9 \pm 0.29$ & $0.9 \pm 0.29$ & $0.9 \pm 0.23$ \\
\hline
\end{tabular}

Note. $R B C$ red blood cell, $H B$ hemoglobin, $H C T$ hematocrit, $M C V$ mean corpuscular volume, $M C H$ mean corpuscular hemoglobin, $M C H C$ mean corpuscular hemoglobin concentration, PLT platelet, RET reticulocytes, NEU neutrophils, LYM lymphocytes, MON monocytes, EOS eosinophils, BAS basophils, LUC large unstained cells

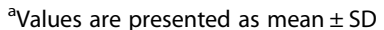

${ }^{*}{ }^{* *} P<0.05, P<0.01$ versus vehicle control group

which was consistent with the previous studies (Fig. 4). In particular, an apparent atrophic change of follicles (B cell area) and periarteriolar lymphoid sheath ( $\mathrm{T}$ cell area) in the spleen and decreased cellularity in the cortex of the thymus were in agreement with the hematological findings of our study and the results of previous studies [7, 54, 55].
The changes in organ weight included increased kidney weight and decreased liver, spleen, and thymus weights in the high dose group of $\mathrm{Cu}$ NPs (Additional file 1: Table S2). These findings were of toxicological significance, because they were well supported by correlated biochemical, hematological, and histopathological changes. In contrast, 


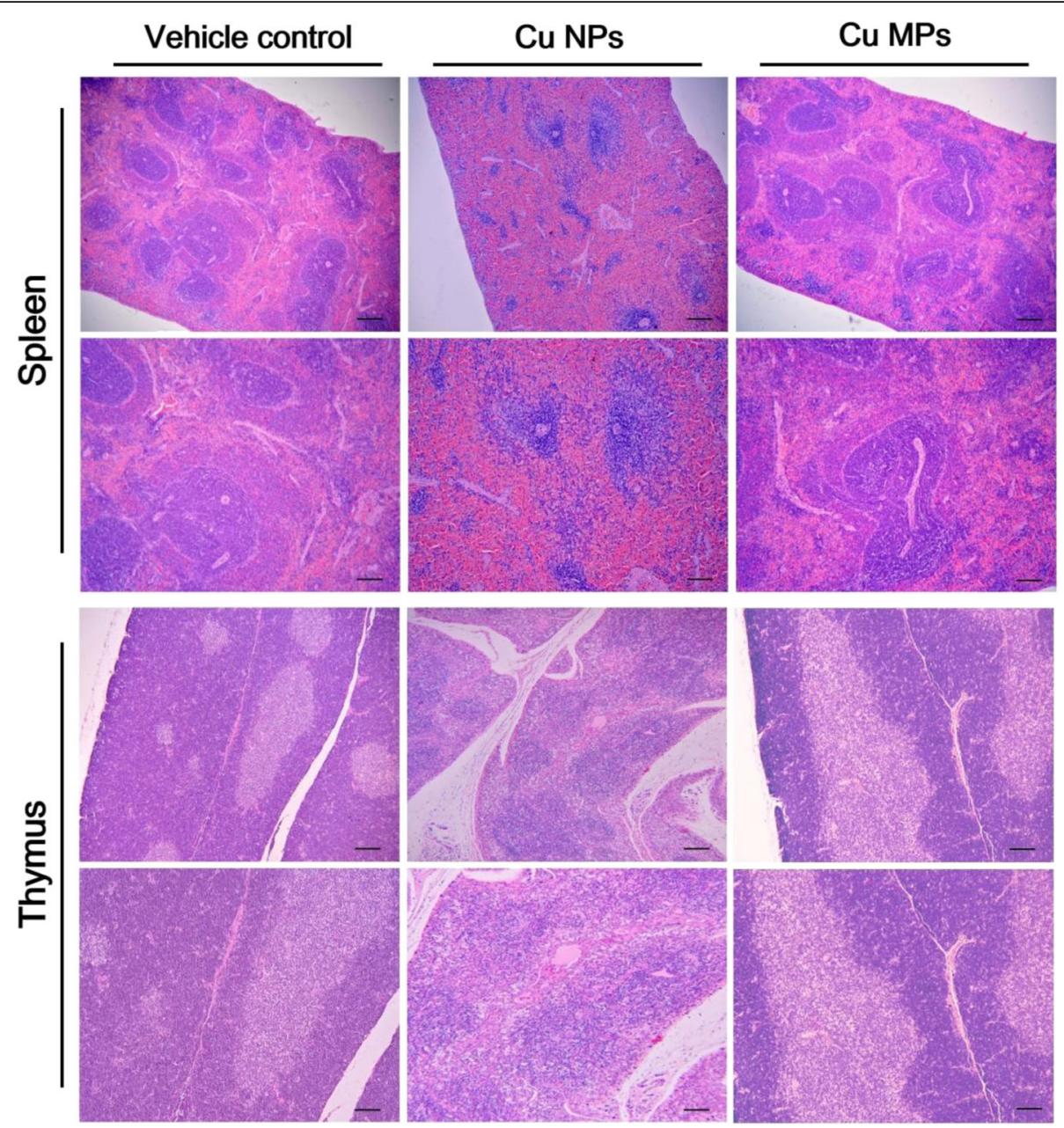

Fig. 4 Histopathological changes in spleen and thymus of rats treated with copper nanoparticles (Cu NPs) and copper microparticles (Cu MPs) following 4 weeks-repeated oral dose. The rats treated with Cu NPs at $400 \mathrm{mg} / \mathrm{kg} /$ day showed moderate to severe degree of atrophic white pulp, decreased number of follicles and cellularity, and yellow pigmentation in spleen, disrupted demarcation of medulla/cortex, decreased cellularity of medulla/cortex, and cytoplasmic vacuolation in thymus. There were no changes in spleen and thymus from rats treated with Cu MPs. Hematoxylin and eosin stain

$\mathrm{Cu}$ MPs-treated rats did not show obvious changes in histopathology and organ weights even at the high dose (Figs. 4, 5, and Additional file 1: Table S3). The remarkable reduction in prostate and seminal vesicle weights was observed at the high dose of $\mathrm{Cu}$ NPs. Chattopadhyay et al. [56] demonstrated that male rats treated with copper chloride at $2 \mathrm{mg} / \mathrm{kg} /$ day intraperitoneally for 26 days displayed adverse effects on testicular spermatogenesis and development of reproductive organs. Test substancerelated stress in the toxicity study causes a decrease in the weights of reproductive organs, including epididymides, seminal vesicles, and prostates, but not in the testes [57]. Thus, further study is needed to determine the potential reproductive/developmental toxicity of $\mathrm{Cu}$ NPs because it is unclear whether decreased reproductive organ weights are related to the anti-androgenic effects of $\mathrm{Cu}$ dissociated from $\mathrm{Cu}$ NPs or to the stress-response phenomenon during the toxicity study.

Exposure to $\mathrm{Cu}$ NPs can occur through various routes (e.g., inhalation, ingestion, injection or physical contact). When administered orally, high solubility in the acidic milieu implies that $\mathrm{Cu}$ NPs can be dissociated into $\mathrm{Cu}$ ions in gastric $\mathrm{pH}$ conditions. Further, higher $\mathrm{Cu}$ levels in blood and tissues in rats treated with $\mathrm{Cu}$ NPs than $\mathrm{Cu}$ MPs indicate that absorbed $\mathrm{Cu}$ ions were distributed via circulation and accumulated in various tissues, which can be a toxic reservoir. Consistent with the above results, the toxicological study revealed that $\mathrm{Cu}$ NPs were more toxic than MPs of the same chemical composition at the same mass. The dissolution of $\mathrm{Cu}$ NPs may have an important role in their toxicity $[7,15] . \mathrm{Cu}$ ion overload caused by excessive $\mathrm{Cu}$ NPs administration 
Table 3 Serum biochemical changes in male rats treated with Cu NPs and Cu MPs following 28 days-repeated oral dose

\begin{tabular}{|c|c|c|c|c|}
\hline \multirow[t]{2}{*}{ Items } & \multicolumn{4}{|c|}{ Cu NPs (mg/kg/day) } \\
\hline & 0 & 100 & 200 & 400 \\
\hline No. of rats & 10 & 10 & 10 & 10 \\
\hline AST (IU/L) & $115.6 \pm 19.32^{a}$ & $125.2 \pm 15.04$ & $258.4 \pm 21.52^{* *}$ & $626.6 \pm 60.04^{* *}$ \\
\hline ALT (IU/L) & $23.7 \pm 2.80$ & $33.3 \pm 12.95$ & $88.4 \pm 20.65^{* *}$ & $115.8 \pm 19.12^{* *}$ \\
\hline ALP $(I U / L)$ & $129.8 \pm 12.45$ & $132.0 \pm 16.08$ & $156.4 \pm 22.06^{*}$ & $175.7 \pm 38.23^{* *}$ \\
\hline BUN (mg/dL) & $19.4 \pm 2.02$ & $20.2 \pm 3.24$ & $22.4 \pm 1.39$ & $40.6 \pm 6.72^{* *}$ \\
\hline CRE (mg/dL) & $0.23 \pm 0.052$ & $0.24 \pm 0.041$ & $0.26 \pm 0.058$ & $0.38 \pm 0.068^{* *}$ \\
\hline CPK (IU/L) & $519.0 \pm 124.43$ & $504.2 \pm 99.57$ & $480.5 \pm 94.72$ & $335.2 \pm 94.70^{* * *}$ \\
\hline TBIL (mg/dL) & $0.25 \pm 0.071$ & $0.24 \pm 0.055$ & $0.34 \pm 0.036$ & $1.07 \pm 0.318^{* *}$ \\
\hline $\mathrm{TCHO}(\mathrm{mg} / \mathrm{dL})$ & $77.6 \pm 8.82$ & $79.7 \pm 8.94$ & $78.7 \pm 2.52$ & $68.6 \pm 14.36$ \\
\hline $\mathrm{TG}(\mathrm{mg} / \mathrm{dL})$ & $142.0 \pm 25.52$ & $133.4 \pm 38.73$ & $102.3 \pm 29.10^{*}$ & $87.3 \pm 28.43^{* *}$ \\
\hline $\mathrm{TP}(\mathrm{g} / \mathrm{dL})$ & $6.2 \pm 0.21$ & $6.1 \pm 0.31$ & $5.4 \pm 0.25^{* *}$ & $5.4 \pm 0.36^{* *}$ \\
\hline ALB (g/dL) & $4.2 \pm 0.36$ & $4.0 \pm 0.12$ & $4.0 \pm 0.23$ & $4.0 \pm 0.17$ \\
\hline LDH (IU/L) & $227.7 \pm 79.76$ & $268.4 \pm 55.99$ & $321.1 \pm 57.63^{*}$ & $462.3 \pm 106.3^{* *}$ \\
\hline $\mathrm{Na}(\mathrm{mEq} / \mathrm{L})$ & $141.8 \pm 0.75$ & $140.2 \pm 1.35$ & $140.3 \pm 1.21$ & $137.8 \pm 2.95^{* *}$ \\
\hline $\mathrm{Cl}(\mathrm{mEq} / \mathrm{L})$ & $97.6 \pm 2.34$ & $96.0 \pm 1.17$ & $95.8 \pm 1.53^{*}$ & $93.4 \pm 1.14^{* *}$ \\
\hline $\mathrm{K}(\mathrm{mEq} / \mathrm{L})$ & $4.5 \pm 0.49$ & $4.8 \pm 0.28$ & $5.1 \pm 0.26$ & $6.0 \pm 1.04^{* *}$ \\
\hline \multirow[t]{2}{*}{ Items } & \multicolumn{4}{|c|}{ Cu MPs (mg/kg/day) } \\
\hline & 0 & 100 & 200 & 400 \\
\hline No. of rats & 10 & 10 & 10 & 10 \\
\hline AST (IU/L) & $113.7 \pm 13.25$ & $135.4 \pm 29.86$ & $138.6 \pm 22.51$ & $138.3 \pm 21.89$ \\
\hline ALT (IU/L) & $24.9 \pm 7.91$ & $27.3 \pm 10.83$ & $24.7 \pm 4.28$ & $24.8 \pm 5.69$ \\
\hline ALP (IU/L) & $124.7 \pm 14.40$ & $147.2 \pm 20.99^{*}$ & $120.4 \pm 18.95$ & $122.8 \pm 11.17$ \\
\hline BUN (mg/dL) & $17.3 \pm 2.94$ & $21.5 \pm 4.85$ & $21.5 \pm 4.72$ & $19.4 \pm 3.67$ \\
\hline CRE (mg/dL) & $0.23 \pm 0.045$ & $0.26 \pm 0.062$ & $0.27 \pm 0.058$ & $0.24 \pm 0.056$ \\
\hline CPK (IU/L) & $534.5 \pm 106.82$ & $522.7 \pm 141.61$ & $559.9 \pm 80.12$ & $516.9 \pm 121.53$ \\
\hline TBIL (mg/dL) & $0.23 \pm 0.045$ & $0.24 \pm 0.062$ & $0.26 \pm 0.058$ & $0.25 \pm 0.056$ \\
\hline $\mathrm{TCHO}(\mathrm{mg} / \mathrm{dL})$ & $80.4 \pm 6.41$ & $77.7 \pm 10.74$ & $89.9 \pm 15.03$ & $77.7 \pm 4.37$ \\
\hline $\mathrm{TG}(\mathrm{mg} / \mathrm{dL})$ & $132.3 \pm 20.45$ & $139.9 \pm 20.17$ & $149.4 \pm 24.16$ & $137.6 \pm 20.76$ \\
\hline $\mathrm{TP}(\mathrm{g} / \mathrm{dL})$ & $6.4 \pm 0.31$ & $6.3 \pm 0.47$ & $6.1 \pm 0.50$ & $6.2 \pm 0.16$ \\
\hline ALB (g/dL) & $4.2 \pm 0.17$ & $4.2 \pm 0.27$ & $4.3 \pm 0.22$ & $4.2 \pm 0.22$ \\
\hline LDH (IU/L) & $256.8 \pm 73.56$ & $236.9 \pm 61.90$ & $298.9 \pm 94.33$ & $356.5 \pm 98.59^{*}$ \\
\hline $\mathrm{Na}(\mathrm{mEq} / \mathrm{L})$ & $140.3 \pm 1.16$ & $141.1 \pm 1.97$ & $143.2 \pm 1.14$ & $141.6 \pm 1.65$ \\
\hline $\mathrm{Cl}(\mathrm{mEq} / \mathrm{L})$ & $97.3 \pm 1.42$ & $98.9 \pm 1.52$ & $97.6 \pm 1.65$ & $99.0 \pm 1.67$ \\
\hline $\mathrm{K}(\mathrm{mEq} / \mathrm{L})$ & $4.6 \pm 0.32$ & $5.1 \pm 0.67$ & $4.5 \pm 0.36$ & $4.6 \pm 0.44$ \\
\hline
\end{tabular}

Note. $A S T$ aspartate aminotransferase, $A L T$ alanine aminotransferase, $A L P$ alkaline phosphatase, $B U N$ blood urea nitrogen, $C R E$ creatinine, $C P K$ creatine phosphokinase, TBIL total bilirubin, $T C H O$ total cholesterol, $T G$ triglyceride, $T P$ total protein, $A L B$ albumin, $L D H$ lactate dehydrogenase, Na sodium, $C l c h l o r i d e$, $K$ potassium

${ }^{a}$ Values are presented as mean \pm SD

${ }^{*}{ }^{* *} P<0.05, P<0.01$ versus vehicle control group

can cause damage to their accumulation sites, especially liver, kidney, and spleen $[15,43]$. Additionally, the toxicity of $\mathrm{CuO}$ NPs was largely explained by soluble $\mathrm{Cu}$ ions [58]. Thus, the differences in dissolution play a crucial role in the gap of toxicological responses between $\mathrm{Cu}$ NPs and $\mathrm{Cu}$ MPs. In addition, the biopersistence of
NPs influences long-term toxicity and is considered to be an important parameter needed for the risk assessment of NPs [36]. Therefore, further studies will be necessary to investigate whether the toxic responses of $\mathrm{Cu}$ NPs observed in this study are transient or persistent responses. 
Table 4 Histological changes in male rats treated with Cu NPs and MPs following 28 days-repeated oral dose

\begin{tabular}{|c|c|c|c|c|c|c|c|c|}
\hline \multirow[t]{2}{*}{ Items } & \multicolumn{4}{|c|}{ Cu NPs (mg/kg/day) } & \multicolumn{4}{|c|}{ Cu MPs (mg/kg/day) } \\
\hline & 0 & 100 & 200 & 400 & 0 & 100 & 200 & 400 \\
\hline No. of rats & 10 & 10 & 10 & 10 & 10 & 10 & 10 & 10 \\
\hline \multicolumn{9}{|l|}{ Liver } \\
\hline Mononuclear cell infiltration & $-(0)^{a}$ & $-(0)$ & $+(4)$ & $++(8)$ & $-(0)$ & $-(0)$ & $-(0)$ & $-(0)$ \\
\hline Dilated sinusoid & $-(0)$ & $+(2)$ & $+(7)$ & $+(9)$ & $-(0)$ & $+(2)$ & $+(2)$ & $+(4)$ \\
\hline Degenerated hepatocytes & $-(0)$ & $-(0)$ & $+(3)$ & $+(9)$ & $-(0)$ & $+(1)$ & $+(2)$ & $+(1)$ \\
\hline Binucleated hepatocytes & $+(1)$ & $+(1)$ & $+(2)$ & $+(7)$ & $+(1)$ & $+(2)$ & $+(3)$ & $+(1)$ \\
\hline \multicolumn{9}{|l|}{ Kidney } \\
\hline Dilated tubules & $-(0)$ & $+(2)$ & $++(3)$ & $++(8)$ & $-(0)$ & $+(1)$ & $+(4)$ & $+(3)$ \\
\hline Cell debris in tubules & $-(0)$ & $-(0)$ & $++(4)$ & $++(8)$ & $-(0)$ & $-(0)$ & $-(0)$ & $-(0)$ \\
\hline Purple-colored casts in tubules & $-(0)$ & $-(0)$ & $+(5)$ & $+++(7)$ & $-(0)$ & $-(0)$ & $-(0)$ & $-(0)$ \\
\hline Degenerated tubular cells & $-(0)$ & $-(0)$ & $+(2)$ & $++(8)$ & $-(0)$ & $-(0)$ & $-(0)$ & $-(0)$ \\
\hline Inflammatory cell infiltration & $-(0)$ & $-(0)$ & $+(2)$ & $+(7)$ & $-(0)$ & $-(0)$ & $-(0)$ & $-(0)$ \\
\hline \multicolumn{9}{|l|}{ Spleen } \\
\hline Atrophic white pulp & $-(0)$ & $-(0)$ & $+(3)$ & $++(7)$ & $-(0)$ & $-(0)$ & $-(0)$ & $-(0)$ \\
\hline Decreased number of follicles & $-(0)$ & $-(0)$ & $+(3)$ & $+++(6)$ & $-(0)$ & $-(0)$ & $-(0)$ & $-(0)$ \\
\hline Decreased cellularity & $-(0)$ & $-(0)$ & $+(1)$ & $++(7)$ & $-(0)$ & $-(0)$ & $-(0)$ & $-(0)$ \\
\hline Yellow pigmentation & $-(0)$ & $-(0)$ & $+(1)$ & $+(5)$ & $-(0)$ & $-(0)$ & $-(0)$ & $-(0)$ \\
\hline \multicolumn{9}{|l|}{ Thymus } \\
\hline Decreased cellularity in medulla/cortex & $-(0)$ & $-(0)$ & $+(2)$ & $++(5)$ & $-(0)$ & $-(0)$ & $-(0)$ & $-(0)$ \\
\hline Disrupted demarcation of medullar/cortex & $-(0)$ & $-(0)$ & $+(2)$ & $++(4)$ & $-(0)$ & $-(0)$ & $-(0)$ & $-(0)$ \\
\hline Cytoplasmic vacuolation & $-(0)$ & $-(0)$ & $-(0)$ & $+(5)$ & $-(0)$ & $-(0)$ & $-(0)$ & $-(0)$ \\
\hline
\end{tabular}

${ }^{a}-$, normal; + , mild; ++ , moderate; +++ , severe; (), number of case

\section{Methods}

\section{Test chemicals and preparation of test chemicals}

$\mathrm{Cu}$ NPs (CAS No. 7440-50-8; $99.8 \%$ purity) and Cu MPs (99\% purity) were purchased from SkySpring Nanomaterials (Houston, TX, USA) and Sigma-Aldrich (St. Louis, MO, USA), respectively. The information of particle size (measured by TEM) of $\mathrm{Cu}$ NPs and $\mathrm{Cu}$ MPs was 25 and 14-25 $\mu \mathrm{m}$, respectively. Hydroxypropylmethylcellulose (HPMC, suspending vehicle) was purchased from Sigma-Aldrich. All other chemicals were of the highest grade commercially available. Test chemicals were dispersed into $1 \%$ HPMC solution (w/v) with Milli-Q water. Particle suspensions were made fresh every day and prepared by ultrasonic dispersion (VCX130, Vibra Cell Sonics \& Materials, Newtown, CT, USA) on ice for $20 \mathrm{~min}(130 \mathrm{~W}$, $20 \mathrm{kHz}$, pulse 59/1) in agreement with recommendations by Taurozzi et al. [59].

\section{Physicochemical characterization and solubility of Cu NPs and Cu MPs}

The primary size and morphology were measured by TEM (JEM-2100 F, JEOL, Tokyo, Japan) operating at $150 \mathrm{kV}$ and SEM (Zeiss EVO-MA10, Carl Zeiss SMT, Cambridge, UK) operating at $15 \mathrm{kV}$. The purity of NPs and MPs was determined by EDX analysis on the same images from TEM (JEM-2100 F TEM equipped with

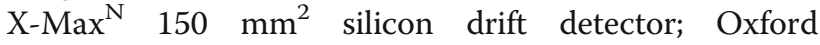
Instruments, UK). The samples for TEM were deposited on carbon-coated nickel grids and were air-dried overnight before analysis. The average size was obtained by measuring at least 100 particles using an image analyzer program (JEOL). The samples for SEM were dispersed on double-sided adhesive carbon tape onto an aluminum SEM stub, and then dusted to release loose particles. The specific surface area of NP and MP powder was measured by the nitrogen $\left(\mathrm{N}_{2}\right)$ absorption based on the multipoint BET method using an ASAP2020 (Micromeritics, Norcross, GA, USA). In the solubility study, $\mathrm{Cu}$ NPs and $\mathrm{Cu}$ MPs were incubated under three physiological conditions: acidic conditions using artificial gastric fluid (AGF, pH 1.5), vehicle (1 \% HPMC, $\mathrm{pH}$ 6.5), and basic conditions using deionized water $(\mathrm{pH} 7.8)$ for $24 \mathrm{~h}$. AGF was prepared according to the previously described method [60]. In brief, $1.0 \mathrm{~g} \mathrm{NaCl}$ (Affymetrix, Santa Clara, CA, USA) and 1.6 g pepsin (Sigma-Aldrich) were dissolved in $500 \mathrm{~mL}$ of DW and the pH of AGF was adjusted to 1.5 using $2 \mathrm{~N} \mathrm{HCl}$ (Sigma-Aldrich). Deionized water ( $\mathrm{pH} 7.8$ ) was used to simulate the basic 


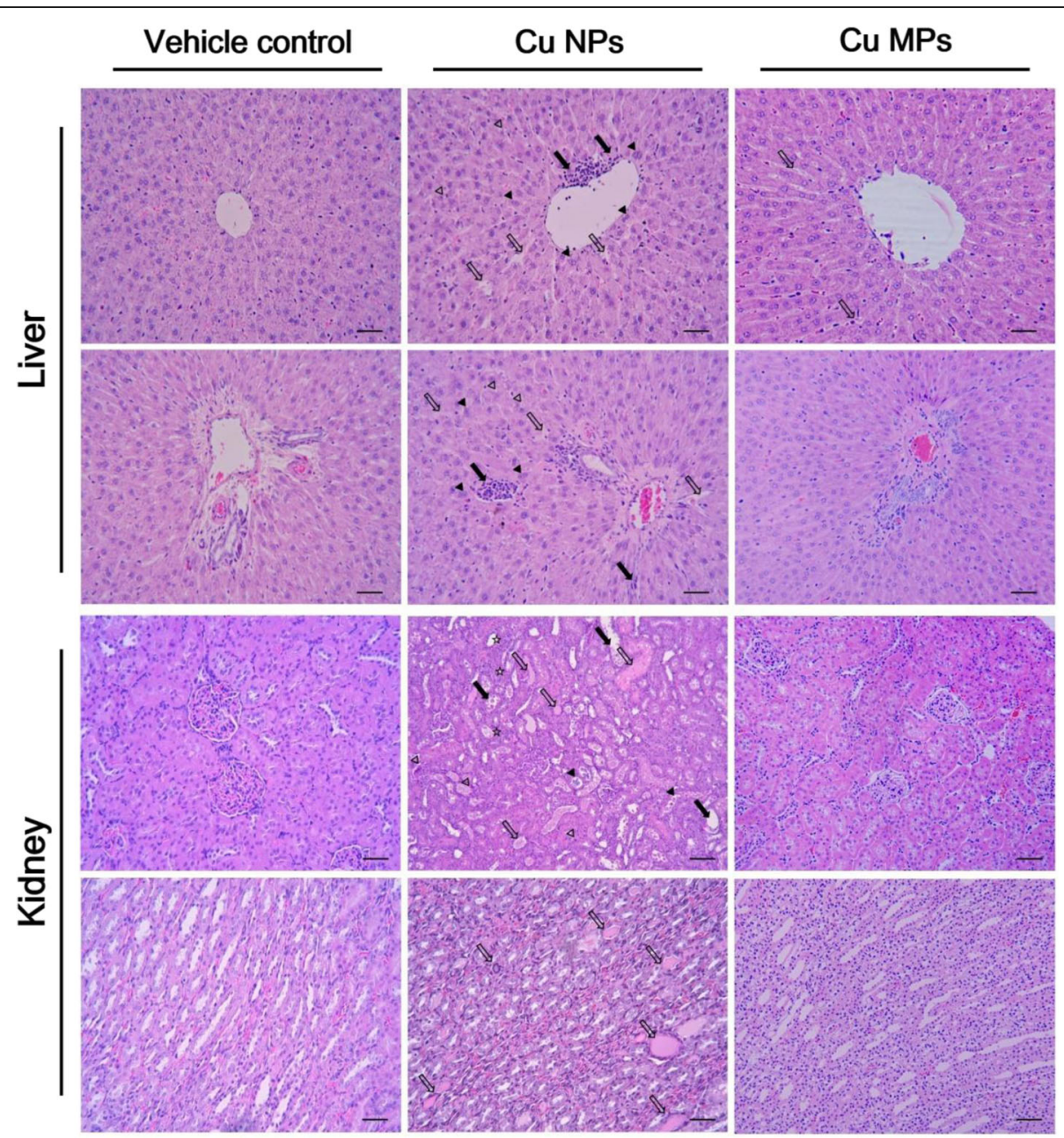

Fig. 5 Histopathological changes in liver and kidney of rats treated with copper nanoparticles (Cu NPs) and copper microparticles (Cu MPs) following 4 weeks-repeated oral dose. Liver from rats treated with Cu NPs at $400 \mathrm{mg} / \mathrm{kg} /$ day showed mononuclear cell infiltration (closed arrows), dilated sinusoid (open arrows), degenerated hepatocytes (vacuolation; open arrowheads), and binucleated hepatocytes (closed arrowheads). The rats treated Cu MPs at $400 \mathrm{mg} / \mathrm{kg} /$ day showed only dilated sinusoid. Kidneys from rats treated with Cu NPs showed dilated tubules (closed arrows), cell debris in tubules (closed arrowheads), pink- or purple-colored cast in tubules (open arrows), degenerated tubular cells (open arrowheads), and inflammatory cell infiltration (asterisks). The rats treated with Cu MPs did not show changes in kidney structure. Hematoxylin and eosin stain

condition. $\mathrm{Cu}$ NPs and $\mathrm{Cu}$ MPs $(5 \mathrm{mg} / \mathrm{mL})$ were incubated in the above solutions for $24 \mathrm{~h}$. NP- or MP-free supernatants were collected by three rounds of centrifugation at $150,000 \times g$ for $30 \mathrm{~min}$ [37]. The samples weighing about $1 \mathrm{~g}$ were placed in $55 \mathrm{~mL}$ microwave digestion vessels and digested with $10 \mathrm{~mL}$ of concentrated nitric acid and $1 \mathrm{~mL}$ of $30 \% \mathrm{H}_{2} \mathrm{O}_{2}$ overnight. The samples were heated in a microwave digestion system (ETHOS One; Milestone, Sorisole, Italy). The microwave digestion system condition was $40{ }^{\circ} \mathrm{C}$ for $1 \mathrm{~min}, 100{ }^{\circ} \mathrm{C}$ for $20 \mathrm{~min}$, and $170{ }^{\circ} \mathrm{C}$ for $2 \mathrm{~h}$ to remove the remaining nitric acid. Afterward, the samples were allowed to cool. After the samples were completely digested and colorless, the remaining solutions were diluted with $2 \%$ nitric acid. The degree of ionization was evaluated by determining $\mathrm{Cu}^{63} \cdot \mathrm{Cu}$ analysis of each sample was carried out using an ICP-MS method (NexION 300X, Perkin Elmer, Waltham, MA, USA). Cu standard solutions for ICP-MS calibration were prepared at concentrations of $5,10,50$, and $100 \mathrm{ng} / \mathrm{g}$. The fraction of solubilized $\mathrm{Cu}$ ions was calculated and expressed as a percentage by dividing the mass of $\mathrm{Cu}$ ions by the initial mass of $\mathrm{Cu}$ in $\mathrm{Cu}$ NPs or $\mathrm{Cu}$ MPs. The hydrodynamic diameter and zeta potential of NPs was measured by the DLS method using ELS8000 (Otsuka Electronics, Tokyo, Japan) equipped with a $633 \mathrm{~nm}$ laser under above simulated physiological milieus.

\section{Animal handling and environmental conditions}

Male Sprague-Dawley rats aged 7 weeks were obtained from a specific pathogen-free colony at Samtako Co. (Osan, Republic of Korea). The animals were acclimated 
for 1 week before starting the experiments. The body weight of the animals at the beginning of the study was $(220 \pm 19 \mathrm{~g})$. Two rats per stainless wire mesh cage were housed in a room maintained at a temperature of $23 \pm$ $3{ }^{\circ} \mathrm{C}$ and a relative humidity of $50 \pm 10 \%$ with artificial lighting from 08:00 to 20:00 and with 13 to 18 air changes per hour. Rats were provided tap water sterilized by ultraviolet irradiation and commercial rodent chow (Samyang Feed, Wonju, Korea) ad libitum. The Institutional Animal Care and Use Committee of Chonnam National University approved the protocols for the animal study (approval number: CNU IACUC-YB-20141 ), and the animals were cared for in accordance with the Guidelines for Animal Experiments of Chonnam National University.

\section{Experimental protocols and dose selection}

The study was carried out in compliance with the Organization for Economic Cooperation and Development (OECD) test guideline TG407 for the testing of chemicals [61]. As males are more susceptible to the toxic effects of $\mathrm{Cu}$ NP than females [7, 15], we utilized male Sprague-Dawley rats for the in vivo toxicity study. A total of 80 healthy male rats were randomly assigned to eight experimental groups $(n=10)$. The test articles were administered by oral gavage to rats at dose levels of 100,200 , and $400 \mathrm{mg} / \mathrm{kg} /$ day, and two vehicle control groups were received $1 \%$ HPMC alone. The experimental doses were selected based on the results of a preliminary dose-range finding study. Three groups of five male rats were exposed to $\mathrm{Cu}$ NPs via oral administration at doses of 50, 200, and $800 \mathrm{mg} / \mathrm{kg} /$ day for 2 weeks. At $800 \mathrm{mg} / \mathrm{kg} /$ day, the male rats displayed obvious general toxicity, such as suppressed body weight gain, decreased food intake, and various clinical signs, as well as death. At $200 \mathrm{mg} / \mathrm{kg} /$ day, $\mathrm{Cu}$ NPs produced a mild decrease in body weight gain and food intake. There were no treatment-related effects on clinical signs, body weights, or food intake at $50 \mathrm{mg} / \mathrm{kg} /$ day. On the basis of these results, $400 \mathrm{mg} / \mathrm{kg} /$ day was used as the high-dose, and the doses of 200 and $100 \mathrm{mg} / \mathrm{kg} /$ day were selected as mid- and low-doses, respectively, using a scaling factor of $\times 2$. The dose levels of $\mathrm{Cu}$ MPs were also selected as 100,200 , and $400 \mathrm{mg} / \mathrm{kg} /$ day equivalent to the dose levels of $\mathrm{Cu}$ NPs for comparing the toxic effects and biodistribution. The administration volume $(10 \mathrm{~mL} /$ $\mathrm{kg}$ body weight) of $\mathrm{Cu}$ NPs and $\mathrm{Cu}$ MPs was calculated based on the body weight of the individual animal measured each week. All animals were observed twice daily (before and after treatment) throughout the study period for any clinical signs of toxicity and mortality. The body weight of each rat and the level of food consumption were measured prior to the beginning of treatment and once a week during the experimental period. The amounts of food were calculated before they were supplied to the cages, and the remnants were measured the next day in order to calculate the difference, which was regarded as daily food consumption (g/rat/day). The weight gain was calculated by body weight on day $28-$ body weight on day 0 . The animals were sacrificed at 24 h (test day 28) after last administration of $\mathrm{Cu}$ NPs or $\mathrm{Cu}$ MPs.

\section{Urinalysis, hematology, and clinical chemistry}

To collect urine and feces, six animals per groups were assigned to a metabolic cage for $6 \mathrm{~h}$ during the last week of the test period (test day 21). Urinalysis was carried out with fresh urine ( $2 \mathrm{~mL}$ per rats) within $1 \mathrm{~h}$ after collection to determine the urine levels of SG, $\mathrm{pH}, \mathrm{PRO}$, LEU, KET, OB, NIT, glucose, bilirubin, and urobilinogen by using the Multistix 10SG reagent strips and the Clinitek Status analyzer (Bayer Healthcare, Leverkusen, Germany). To collect blood samples, the animals underwent fasting overnight before scheduled necropsy (test day 28). During the scheduled necropsy, the blood samples (approximately $4 \mathrm{~mL}$ ) were collected from the vena cava under carbon dioxide anesthesia. Approximately $1 \mathrm{~mL}$ of blood was collected in CBC bottles containing EDTA-2 $\mathrm{K}$ and analyzed within $1 \mathrm{~h}$ using an automatic hematology analyzer (Bayer ADVIA 120 Hematology Analyzer System, Leverkusen, Germany). Samples were analyzed for RBC (erythrocyte), HB, HCT, MCV, MCH, $\mathrm{MCHC}$, platelets, WBC (leukocyte) count and the differential count of WBC. A portion of the blood (about $3 \mathrm{~mL}$ ) was placed into tubes for serum separation and incubated at room temperature within $90 \mathrm{~min}$. Serum samples were collected by centrifugation at $5000 \times g$ for 10 min and evaluated with a blood chemistry autoanalyzer (Dri-chem 4000i, Fujifilm Co., Tokyo, Japan) for the following: AST, ALT, ALP, TP, BUN, CRE, TG, TBIL, glucose, albumin, total cholesterol, chloride, sodium, and potassium within $3 \mathrm{~h}$ after blood collection. After analysis of urine and blood, remaining urine and blood samples were stored immediately at $-80{ }^{\circ} \mathrm{C}$ before $\mathrm{Cu}$ concentration analysis.

\section{Organ weights and histology}

All organs were removed, weighed, and examined for macroscopically visible lesions. The weights of the following organs were measured: brain, thymus, heart, lung, liver, spleen, kidneys, adrenal glands, testes, seminal vesicles, prostates, and epididymides. The histopathological evaluation of organs and tissues was performed by fixing in a $10 \%$ neutral-buffered formalin solution for 1 week. The tissues were stained with hematoxylin and eosin for microscopic examination. All observations were made manually in a blinded manner 
using a light microscope with $\times 5, \times 10, \times 20$, and $\times 40$ objective lenses and $\mathrm{a} \times 100$ oil immersion lens.

\section{In vivo absorption, distribution, and excretion of $\mathrm{Cu}$ from Cu NPs or Cu MPs}

After The concentration of $\mathrm{Cu}$ in blood, tested organs (liver, kidney, spleen, heart, lung, and brain), urine and feces was determined by ICP-MS. Absorption of $\mathrm{Cu}$ in the $\mathrm{Cu}$ NP-treated rats was determined by using blood samples. To evaluate tissue distribution, tissue samples from the liver (left part of median lobe), spleen (left half), kidney (part of left kidney), lung (part of left lobe), heart (left half), and brain (left hemisphere) were obtained and weighed. Excretion of $\mathrm{Cu}$ was measured in urine and feces. The tissues, feces (about $0.3 \mathrm{~g}$ ) or blood and urine (about $2 \mathrm{~mL}$ ) samples were weighed and digested with concentrated nitric acid and $30 \% \mathrm{H}_{2} \mathrm{O}_{2}$ overnight. The samples were heated in a microwave digestion system (Milestone) at $170{ }^{\circ} \mathrm{C}$ to remove the remaining nitric acid until the samples were completely digested and till they became colorless. Finally, remaining solutions were diluted with $2 \%$ nitric acid to a final acid concentration of 8-12\%. All samples were analyzed in duplicates for elemental $\mathrm{Cu}$ concentration $\left(\mathrm{Cu}^{63}\right)$ using ICP-MS methods (Perkin Elmer, MA, USA).

\section{Statistical analysis}

The numerical data were presented as means \pm standard deviations (SD), and all statistical comparisons were analyzed by one-way analysis of variance (ANOVA) followed by Dunnett's multiple comparison test. The urinalysis data were rank-transformed and analyzed by the nonparametric Kruskal-Wallis $\mathrm{H}$-test. If a statistically significant difference was observed between groups, the Mann-Whitney $U$-test was used to identify the groups that were significantly different from the vehicle control group. A $P$ value of $<0.05$ was considered significant. Statistical analyses were performed using the GraphPad InStat v.3.0 (GraphPad Software, Inc., CA, USA).

\section{Conclusions}

We described the in vivo toxicity and biodistribution of $\mathrm{Cu}$ NPs and $\mathrm{Cu}$ MPs following repeated oral exposure. The greater reactive surface area originating from its small size can lead to high reactivity, subsequently inducing rapid dissolution of $\mathrm{Cu}$ NPs in an acidic milieu. Thus, $\mathrm{Cu}$ NPs may be readily dissociated into their ionic forms in stomach compared with micro-size particles of the same composition. This is demonstrated by the $\mathrm{Cu}$ levels in blood and tested organs after $\mathrm{Cu}$ NP or $\mathrm{Cu}$ MP exposure. In vivo repeated dose toxicity study demonstrated that high surface area and high solubility could contribute to the toxicological responses of particles by causing $\mathrm{Cu}$ ion overload in their accumulation sites. $\mathrm{Cu}$ NPs affected RBC, liver, kidney, and immune organs (spleen and thymus), as well as male accessory reproductive organs at $\geq 200 \mathrm{mg} / \mathrm{kg} /$ day, whereas Cu MPs did not cause obvious changes at $\leq 400 \mathrm{mg} / \mathrm{kg} /$ day. Under these experimental conditions, the no-observed-adverseeffect level of $\mathrm{Cu}$ NPs and $\mathrm{Cu}$ MPs was considered to be $100 \mathrm{mg} / \mathrm{kg} /$ day and $\geq 400 \mathrm{mg} / \mathrm{kg} /$ day, respectively. In light of our findings, dissolution in physiological milieus influences absorption and biodistribution and acts as a determination factor in the toxic responses of particles in vivo when administered orally.

\section{Additional file}

Additional file 1: Table S1. Urinalysis findings in male rats treated with Cu NPs or Cu MPs following 28 days-repeated oral dose. Table S2. Absolute and relative organ weights in male rats treated with Cu NPs following 28 days-repeated oral dose. Table S3. Absolute and relative organ weights in male rats treated with Cu MPs following 28 days-repeated oral dose. (DOCX $47 \mathrm{~kb}$ )

\section{Abbreviations}

AGF: Artificial gastric fluid; ALP: Alkaline phosphatase; ALT: Alanine aminotransferase; AST: Aspartate aminotransferase; BET: Brunauer-EmmettTeller; BUN: Blood urea nitrogen; CRE: Creatinine; Cu MPs: Copper microparticles; Cu NPs: Copper nanoparticles; CuO NPs: Copper oxide nanoparticles; DLS: dynamic light scattering; EDX: Energy dispersive X-ray spectroscopy; $\mathrm{H}^{+}$: Hydrogen ion; $\mathrm{HB}$ : Hemoglobin; $\mathrm{HCO}_{3}^{-}$: Bicarbonate; HCT: Hematocrit; HPMC: Hydroxypropylmethylcellulose; ICP-MS: Inductively coupled plasma mass spectrometry; LDH: Lactate dehydrogenase;

LEU: Leukocytes; MCH: Mean corpuscular hemoglobin; MCHC: Mean corpuscular hemoglobin concentration; MCV: Mean corpuscular volume; NIT: Nitrite; OB: Occult blood; PRO: Protein; RBC: Red blood cell; RET: Reticulocytes; SD: Standard deviation; SEM: Scanning electron microscopy; SG: Specific gravity; TBIL: Total bilirubin; TEM: Transmission electron microscopy; TG: Triglyceride; TP: Total protein;

\section{Acknowledgements}

The animal experiment in this study was supported the Animal Medical Institute of Chonnam National University.

\section{Funding}

This research was supported by a grant (16182MFDS384) from Ministry of Food and Drug Safety in 2016.

\section{Authors' contributions}

$I C L$ and JCK designed the experimental approach and wrote the manuscript. JWK, SHP, and ISS refined the experimental protocols. ICL, NRS, and JHK performed the animal experiments, physicochemical analyses of particle suspensions. ICL, JWK, and JHK performed the urinalysis, hematology, and serum biochemistry. NRS and SHP performed preparation of tissue samples for ICP-MS analysis. Statistical analyses were done by ICL, JWK, and CM. CM, HCK, and JCK refined manuscript. All authors reviewed and approved the final manuscript.

\section{Competing interests}

The authors declared that they have no competing interests.

\section{Consent for publication}

Not applicable.

Ethics approval and consent to participate Not applicable. 


\section{Author details}

'College of Veterinary Medicine BK21 Plus Project Team, Chonnam National University, Gwangju 61186, Republic of Korea. ${ }^{2}$ Natural Product Research Center, Korea Research Institute of Bioscience and Biotechnology, Jeongeup 56212, Republic of Korea. ${ }^{3}$ Gyeongnam Department of Environment \& Toxicology, Korea Institute of Toxicology, Gyeongnam 52834, Republic of Korea. ${ }^{4}$ Laboratory Animal Resource Center, Korea Research Institute of Bioscience and Biotechnology, ChungBuk 28116, Republic of Korea.

\section{Received: 12 April 2016 Accepted: 17 October 2016}

\section{Published online: 28 October 2016}

\section{References}

1. Dowling A, Clift R, Grobert N, Hutton D, Oliver R, O'neill O, Pethica J, Pidgeon N, Porritt J, Ryan A, Seaton A, Tendler S, Welland M, Whatmore R. Nanoscience and nanotechnology: opportunities and uncertainties. The Royal Society \& The Royal Academy of Engineering Report London, UK. 2004;61:e64

2. Aillon KL, Xie Y, El-Gendy N, Berkland CJ, Forrest ML. Effects of nanomaterials physicochemical properties on in vivo toxicity. Adv Drug Deliv Rev. 2009;61(6):457-66.

3. Oberdörster G, Oberdörster E, Oberdörster J. Nanotoxicology: an emerging discipline evolving from studies of ultrafine particles. Environ Health Perspect. 2005:113(7):823-39.

4. Oberdörster G. Extrapolation of results from animal inhalation studies with particles to humans? In: Mohr U, Dungworth DL, Mauderly JL, Oberdörster $G$, editors. Toxic and carcinogenic effects of solid particles in the respiratory tract. Washington DC: ILSI Press; 1994. p. 335-53.

5. Donaldson K, Li XY, Mac NW. Ultrafine (nanometer) particle mediated lung injury. J Aerosol Sci. 1998;29(5-6):553-60.

6. Warheit DB, Laurence BR, Reed KL, Roach DH, Reynolds G, Webb TR. Comparative pulmonary toxicity assessment of single-wall carbon nanotubes in rats. Toxicol Sci. 2004;77(1):117-25.

7. Chen Z, Meng H, Xing GM, Chen CY, Zhao YL, Jia G, Wang TC, Yuan H, Ye C, Zhao F, Chai ZF, Zhu CF, Fang XH, Ma BC, Wan LJ. Acute toxicological effects of copper nanoparticles in vivo. Toxicol Lett. 2006;163(2):109-20.

8. Yallapu MM, Chauhan N, Othman SF, Khali izad-Sharghi V, Ebeling MC, Khan S, Jaggi M, Chauhan SC. Implications of protein corona on physic-chemical and biological properties of magnetic nanoparticles. Biomaterials. 2015;46:1-12.

9. Giles J. Nanotechnology: What is there to fear from something so small? Nature. 2003:426:750.

10. Maynard AD, Kuempel ED. Airborne nanostructured particles and occupational health. J Nanopart Res. 2005;7(6):587-614.

11. Agarwal M, Murugan MS, Anupama S, Rai R, Kamboj A, Sharma H, Roy S. Nanoparticles and its toxic effects: a review. Int I Curr Microbiol App Sci. 2013;2(10):76-82.

12. Uauy R, Olivares M, Gonzalez M. Essentiality of copper in humans. Am J Clin Nutr. 1998:67(5):952S-9.

13. Turnlund JR. Copper. In: Shils ME, Olson JA, Shike M, Ross AC, editors. Modern nutrition in health and disease. 9th ed. Baltimore: Williams and Wilkins; 1999.

14. ATSDR (Agency for Toxic Substances and Disease Registry). Atlanta, GA. 2004. Toxicological profile for copper. http://www.atsdr.cdc.gov/toxprofiles/ tp132.pdf. Accessed 4 Apr 2016.

15. Meng H, Chen Z, Xing GM, Yuan H, Chen CY, Zhao F, Zhang CC, Zhao YL. Ultrahigh reactivity provokes nanotoxicity: explanation of oral toxicity of nano-copper particles. Toxicol Lett. 2007;175(1-3):102-10

16. Ebrahimnia-Bajestan E, Niazmand H, Duangthongsuk W, Wongwises S. Numerical investigation of effective parameters in convective heat transfer of nanofluids flowing under a laminar flow regime. Int J Heat Mass Transfer. 2011:54(19-20):4376-88.

17. Bondarenko O, Juganson K, Ivask A, Kasemets K, Mortimer M, Kahru A. Toxicity of $\mathrm{Ag}$, $\mathrm{CuO}$ and $\mathrm{ZnO}$ nanoparticles to selected environmentally relevant test organisms and mammalian cells in vitro: a critical review. Arch Toxicol. 2013;87:1181-200.

18. Esteban-Tejeda L, Malpartida F, Esteban-Cubillo A, Pecharroman C, Moya JS. Antibacterial and antifungal activity of a soda-lime glass containing copper nanoparticles. Nanotechnology. 2009;20(50):505701.

19. Ingle AP, Duran N, Rai M. Bioactivity, mechanism of action, and cytotoxicity of copper-based nanoparticles: a review. Appl Microbiol Biotechnol. 2014;98:1001-9.
20. Jing X, Park JH, Peters TM, Thorne PS. Toxicity of copper oxide nanoparticles in lung epithelial cells exposed at the air-liquid interface compared with in vivo assessment. Toxicol In Vitro. 2015;29(3):502-11.

21. Kahru A, Savolainen K. Potential hazard of nanoparticles: from properties to biological and environmental effects. Toxicology. 2010;269(2-3):89-91.

22. Fahmy B, Cormier SA. Copper oxide nanoparticles induce oxidative stress and cytotoxicity in airway epithelial cells. Toxicol In Vitro. 2009;23(7):1365-71.

23. Prabhu BM, Ali SF, Murdock RC, Hussain SM, Srivatsan M. Copper nanoparticles exert size and concentration dependent toxicity on somatosensory neurons of rat. Nanotoxicology. 2010;4(2):150-60.

24. Siddiqui MA, Alhadlaq HA, Ahmed J, Al-khedhairy AA, Musarrat J, Ahamed M. Copper oxide nanoparticles induced mitochondria mediated apoptosis in human hepatocarcinoma cells. PLoS ONE. 2013;8(8):e69534. doi:10.1371/ journal.pone.0069534.

25. Misra SK, Nuseibeh S, Dybowska A, Berhanu D, Tertely TD, Valsami-Jones E. Comparative study using spheres, rods and spindle-shaped nanoplatelets on dispersion stability, dissolution and toxicity of $\mathrm{CuO}$ nanomaterials. Nanotoxicology. 2014;8(4):422-32.

26. Rodhe Y, Skoglund S, Wallinder IO, Potacova Z, Moller L. Copper-based nanoparticles induce high toxicity in leukemic HL60 cells. Toxicol in Vitro. 2015;29(7):1711-9

27. Karlsson HL, Cronholm P, Gustafsson J, Moller L. Copper oxide nanoparticles are highly toxic: a comparison between metal oxide nanoparticles and carbon nanotubes. Chem Res Toxicol. 2008;21(9):1726-32.

28. Lei RH, Wu CQ, Yang BH, Ma HZ, Shi C, Wang QJ, Wang QX, Yuan Y, Liao MY. Integrated metabolomic analysis of the nano-sized copper particleinduced hepatotoxicity and nephrotoxicity in rats: A rapid in vivo screening method for nanotoxicity. Toxicol Appl Pharm. 2008;232(2):292-301.

29. Manna P, Ghosh M, Ghosh J, Das J, Sil PC. Contribution of nano-copper particles to in vivo liver dysfunction and cellular damage: role of $1 \mathrm{kBa} / \mathrm{NF}-\mathrm{kB}$, MAPKs and mitochondrial signal. Nanotoxicology. 2012;6(1):1-21.

30. Chun AL. Will the public swallow nanofood? Nat Nanotechnol. 2009:4(12):790-1.

31. Rashidi L, Khosravi-Darani K. The applications of nanotechnology in food industry. Crit Rev Food Sci Nutr. 2011;51(8):723-30.

32. Corrigan JF, Fuhr O, Fenske D. Metal chalcogenide clusters on the border between molecules and materials. Adv Mater. 2009;21:1867-71.

33. Bayat N, Lopes VR, Scholermann J, Jenson LD, Cristobal S. Vascular toxicity of ultra-small $\mathrm{TiO}_{2}$ nanoparticles and single walled carbon nanotubes in vitro and in vivo. Biomaterials. 2015;63:1-13.

34. Xie Y, Williams NG, Tolic A, Chrisler WB, Teeguarden JG, Maddux BL, Pounds $\mathrm{JG}$, Laskin A, Orr G. Aerosolized ZnO nanoparticles induce toxicity in alveolar type II epithelial cells at the air-liquid interface. Toxicol Sci. 2012:125(2):450-61.

35. Bergin IL, Witzmann FA. Nanoparticle toxicity by the gastrointestinal route: evidence and knowledge gaps. Int Biomed Nanosci Nanotechnol. 2013;3(1-2):163-210

36. Utembe W, Potgieter K, Stefaniak AB, Gulumian M. Dissolution and biodurability: important parameters needed for risk assessment of nanomaterials. Part Fibre Toxicol. 2015;12:11.

37. Cho WS, Kang BC, Lee JK, Jeong J, Che JH, Seok SH. Comparative absorption, distribution, and excretion of titanium dioxide and zinc oxide nanoparticles after repeated oral administration. Part Fibre Toxicol. 2013:10:9.

38. Adamcakova-Dodd A, Stebounova LV, Kim JS, Vorrink SU, Ault AP, O'Shaughnessy PT, Grassian VH, Thorne PS. Toxicity assessment of zinc oxide nanoparticles using sub-acute and sub-chronic murine inhalation models. Part Fibre Toxicol. 2014:11:15.

39. Cho WS, Duffin R, Poland CA, Duschl A, Oostingh GJ, MacNee W, Bradley M, Megson IL, Donaldson K. Differential pro-inflammatory effects of metal oxide nanoparticles and their soluble ions in vitro and in vivo; zinc and copper nanoparticles, but not their ions, recruit eosinophils to the lungs. Nanotoxicology. 2012;6(1):22-35.

40. Abbott LC, Maynard AD. Exposure assessment approaches for engineered nanomaterials. Risk Anal. 2010;30(11):1634-44.

41. Saptarshi SR, Duschl A, Lopata AL. Interaction of nanoparticles with proteins: relation to bio-reactvity of the nanoparticle. J Nanobiotechnol. 2013;11:26.

42. Rahman M, Laurent S, Tawil N, Yahia LH, Mahmoudi M. Nanoparticle and protein corona. In: Martinac B, editor. Protein-nanoparticle interactions. Berlin: Springer; 2013. p. 21-44 
43. Feng W, Nie W, Cheng Y, Zhou X, Chen L, Qiu K, Chen Z, Zhu M, He C. In vitro and in vivo toxicity studies of copper sulfide nanoplates for potential photothermal applications. Nanomedicine. 2015;11(5):901-12.

44. Turnlund JR. Human whole-body copper metabolism. Am J Clin Nutr. 1998;67(5):960-4.

45. Semple AB, Parry WH, Philips DE. Acute copper poisoning: an outbreak traced to contaminated water from a corroded geyser. Lancet. 1960;2(7152):700-1.

46. Winge DR, Mehra RK. Host defenses against copper toxicity. Int Rev Exp Pathol. 1990;31:47-83.

47. Barceloux DG. Copper. J Toxicol Clin Toxicol. 1999;37:217-37.

48. Galla JH. Metabolic alkalosis. J Am Soc Nephrol. 2000;11:369-75.

49. Chung MK, Baek SS, Lee SH, Kim H, Choi K, Kim JC. Combined repeated dose and reproductive/developmental toxicities of copper monochloride in rats. Environ Toxicol. 2009:24:315-26.

50. Al-Naimi RA, Al-Tayar NH, Alsoufi LAM, Al-Taae EHY. Hematological and biochemical evaluation after different orally doses of copper sulfate in rats. Iraqi J Vet Med. 2013;38(1):83-91.

51. Hébert CD, Elwell MR, Travlos GS, Fitz CJ, Bucher JR. Subchronic toxicity of cupric sulfate administered in drinking water and feed to rats and mice. Fundam Appl Toxicol. 1993;21:461-75.

52. Arredondo M, Núñez MT. Iron and copper metabolism. Mol Aspects Med. 2005;26:313-27.

53. Pocino M, Baute $L$, Malave I. Influence of the oral administration of excess copper on the immune response. Fundam Appl Toxicol. 1991;16:249-56.

54. Mitra S, Keswani T, Dey M, Bhattacharya S, Sarkar S, Goswami S, Ghosh N, Dutta A, Bhattacharyya A. Copper-induced immunotoxicity involves cell arrest and cell death in the spleen and thymus. Toxicology. 2012;293:78-88.

55. Mitra S, Keswani T, Ghosh N, Goswami S, Datta A, Das S, Maity S, Bhattacharyya A. Copper induced immunotoxicity promote differential apoptotic pathways in spleen and thymus. Toxicology. 2013;306:74-84

56. Chattopadhyay A, Sarkar M, Biswas NM. Dose-dependent effect of copper chloride on male reproductive function in immature rats. Kathmandu Univ Med J. 2005;3(4):392-400.

57. Everds NE, Snyder PW, Bailey KL, Bolon B, Creasy DM, Foley GL, Rosol TJ, Sellers $T$. Interpreting stress responses during routine toxicity studies: a review of the biology, impact, and assessment. Toxicol Pathol. 2012;41(4):560-614.

58. Heinlaan M, Ivask A, Blinova I, Dubourguier HC, Kahru A. Toxicity of nanosized and bulk $\mathrm{ZnO}, \mathrm{CuO}$ and $\mathrm{TiO}_{2}$ to bacteria Vibrio fischeri and crustaceans Daphnia magna and Thamnocephalus platyurus. Chemosphere. 2008:71:1308-16.

59. Taurozzi JS, Hackely VA, Wiesner MR. Ultrasonic dispersion of nanoparticles for environmental, health and safety assessment - issues and recommendations. Nanotoxicology. 2011;5:4.

60. Wurster DE, Burke GM, Berg MJ, Veng-Pedersen P, Schottelius DD. Phenobarbital adsorption from simulated intestinal fluid, U.S.P., and simulated gastric fluid, U.S.P., by two activated charcoals. Pharm Res. 1988:5(3):183-6.

61. OECD (Organization for Economic Cooperation and Development). Paris, France. 2008. OECD Guidelines for the testing of chemicals. Test No. 407: Repeated dose 28-day oral toxicity study in rodents. http://ntp.niehs.nih.gov/ iccvam/suppdocs/feddocs/oecd/oecdtg407-2008.pdf. Accessed 5 Apr 2016

\section{Submit your next manuscript to BioMed Central and we will help you at every step:}

- We accept pre-submission inquiries

- Our selector tool helps you to find the most relevant journal

- We provide round the clock customer support

- Convenient online submission

- Thorough peer review

- Inclusion in PubMed and all major indexing services

- Maximum visibility for your research

Submit your manuscript at www.biomedcentral.com/submit
Biomed Central 